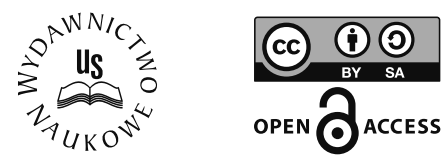

\title{
JANUSZ LEMAŃSKI
}

Uniwersytet Szczeciński, Polska | Instytut Nauk Teologicznych

ORCID: 0000 0002-1512-997X

\section{„Woda oczyszczenia” i jej parakultowe zastosowanie (Lb 19,1-22) jako problem egzegetyczny i teologiczny}

\author{
“WATER OF PURIFICATION” AND ITS PARACULT APPLICATION (NM 19,1-22) \\ AS AN EXEGETICAL AND THEOLOGICAL PROBLEM
}

\section{Summary}

The ritual of slaughtering of a red cow, the preparation of water of purification, and its use in cases of contamination through contact with the sphere of death seem unusual and out of place. Nevertheless, the article attempts to justify why Nm 19 nevertheless has a place. The pericope is classified here as a post-priestly text in which a new aspect is introduced: care for the ritual cleanliness of the sanctuary and community despite everyday contact with the sphere of death and the control of this cleanliness by the priests. A new aspect is precisely this concern for maintaining the purity of the ritual community despite the inevitable contact with the bodies of the deceased. The ritual described in the text is first expressed in a unique method of purification (on the third and seventh day), and then also explains that everything takes place outside the camp, but both priests and laity have their parts in the proceedings. Finally, it is also unique that the priests cure impurity as a result of participating in the ritual of preparing the water of cleansing. Everything takes place outside the sacrificial system, somewhat on its periphery, imitating the atoning sacrifices for sin and producing similar effects to them, but without being such victims. In this way, the legislator wishes, on the one hand, to preserve the ritual character of the rites and to leave them under the supervision of the priests. On the other hand, it aims to maintain the widest possible access to ritual cleansing with the help of water mixed with the ash from a red cow. At the same time, the legislator is aware that the entire procedure is and should remain non-cultic in nature.

Keywords: red cow, cleansing, cleansing water, death 


\section{Wstęp}

Rytuał spalenia „czerwonej krowy” (Lb 19,1-10) i zastosowania potem uzyskanego z niej popiołu (Lb 19,11-22) stanowi jedną z dwóch interesujących anomalii kultowych znajdujących się w Księdze Liczb (por. jeszcze Lb 5,11-31). W obu przypadkach umiejscowienie kontekstualne i nietypowa forma rytuałów tu opisanych może mieć jednak swoje uzasadnienie, jeśli zdoła się zrozumieć intencje ich autorów oraz znaleźć właściwe odniesienia. Obu wskazanym kwestiom, mając na uwadze procedury opisane w Lb $19^{1}$, chcemy się przyjrzeć, opierając się na aktualnym stanie badań.

Prawodawca ma tym razem na uwadze jedną z najcięższych form kontaminacji: kontakt z ciałem zmarłego, jego kośćmi, grobem, (zamkniętą) przestrzenią, w której spoczywają zwłoki. Jest świadom zagrożenia, jakie z tego płyną dla rytualnej czystości sanktuarium i tym samym dla całej wspólnoty (Lb 19,13.20!). Wie i przypomina adresatom tego rytuału pilną potrzebę wyeliminowania takiego zagrożenia. Nie czyni w tej materii żadnej różnicy pomiędzy Izraelitami i nie-Izraelitami. Proponowana przez niego rytualno-kultowa osnowa ideowa całej procedury (jej umiarkowane podobieństwo do ofiary za grzechy) nakłada się jednak na niezwykły, pozakultowy i nieofiarniczy rytuał oczyszczenia, odbywający się poza obozem i tym samym poza sanktuarium, oraz na niepowtarzalną i tajemniczą procedurę uzyskiwania popiołu z czerwonej krowy, spalanej w całości wraz z dodatkami. Symboliczne znaczenie koloru krowy i samych dodatków pozostaje do dziś przedmiotem dyskusji, w której brak konsensusu. Podobnie rzecz się ma z tajemniczą dwuznacznością kontaktu z „wodą oczyszczenia”, która powoduje oczyszczenie i zarazem kontaminację uczestników.

Wszystko to sprawia, że Lb 19 stanowi nie tylko nietypową perykopę zawierającą równie nietypowy rytuał, lecz także tekst robiący wrażenie pewnego novum teologicznego stojącego za zawartymi tu przepisami.

\section{Kontekst}

Na pierwszy rzut oka mamy do czynienia z izolowanym w kontekście fragmentem rytualnym, niepasującym nie tylko do miejsca, w którym aktualnie się znajduje, ale i w ogóle do kapłańskich tekstów rytualnych. W Lb 13-14/16-17 opowiada się o buntach przeciwko boskiemu i ludzkiemu przewodnictwu nad Izraelem. W tekstach bezpośrednio poprzedzających Lb 19 mowa jest o buncie Koracha (Lb 1617) oraz przywilejach i obowiązkach kapłanów/lewitów (Lb 18). Rebelia kończy

1 Na temat Lb 5,11-31 zob. J. Lemański, Biblijne ordalia? Od procedury „sądu Bożego” do ceremoniału kultowego (Lb 5,11-31), „Studia Koszalińsko-Kołobrzeskie” 27 (2020), s. 87-122. 
się zatem karą i śmiercią rebeliantów (Lb 17) oraz zdefiniowaniem na nowo roli kapłanów i lewitów (Lb 18,1-7.22-23). Późniejsze wydarzenia rozgrywają się w Kadesz (Lb 20,1-13), gdzie umiera Miriam i zapowiada się śmierć Aarona oraz Mojżesza (por. Lb 20,22-29: śmierć Aarona).

Faktem jest zatem, że kontekst Lb 16-17 i Lb 20 stanowi doświadczenie śmierci. W badaniach nad Lb 19 znaleźć więc można sugestie, że rytuał z czerwoną krową i wodą oczyszczenia pojawia się w obecnym miejscu ze względu na śmiercionośne skutki rebelii Koracha (Lb 16,30-35) ${ }^{2}$. Takie powiązanie mogłoby wzmacniać także użycie słowa lāqah - „Wziąć” (Lb 19, 3.4.6.17.18; por. Lb 16,1.6.17.18) Jeszcze wcześniej, w Lb 14 ogłasza się wręcz bliską śmierć całego pierwszego pokolenia exodusu. Niemniej w samej perykopie z Lb 19 przepisany rytuał powiązany został raczej z przypadkami śmierci zachodzącymi w życiu codziennym (Lb 19,11a.13a.14.16), a nie w wyniku doświadczenia jakiejś kary bożej. Ponadto, gdyby chciało się wiązać ten rytuał ze skutkami rebelii Koracha, to logicznej byłoby umieścić go w Lb 17 lub zaraz po tym rozdziale. Nawet i bez takich powiązań potem cały rytuał - mimo licznych , anomalii” kultowych w nim obecnych (w stosunku do zasad charakterystycznych dla rytuałów P/post-P) - lepiej pasowałby w kontekście przepisów z Kpł 11-15, gdzie zgromadzone są powygnaniowe praktyki i ceremoniały dotyczące rytualnej czystości

Zasady podane w Lb 18 dotyczą z kolei obowiązków spoczywających na kapłanach i lewitach w strzeżeniu świętości sanktuarium (Namiotu Spotkania) przed ewentualną profanacją. Praktyki zawarte w Lb 19 wskazują, jak oczyścić się z najcięższej z kontaminacji zagrażających sanktuarium (Lb 19,13.20). Niemniej i w tym wypadku związek jest bardzo luźny.

W sumie jedyny pewny związek kontekstualny zachodzi pomiędzy Lb 19,1-22 i Lb 31,19-24. Drugi z tych tekstów stanowi wyraźne echo interesującej nas tu perykopy. W obu miejscach chodzi o uniknięcie kolektywnej nieczystości wynikającej z kontaktu jednostki z ciałem zmarłego lub tym, co pozostaje w sferze śmierci (por. Lb 19,11.14-16; 31,19-24).

Niemniej obecna lokalizacja perykopy z Lb 19,1-22 nie jest całkowicie oderwana od najbliższego kontekstu. Zaczyna się ona od wskazania dwóch adresatów, do których skierowane zostają słowa Jhwh, Mojżesza i Aarona (Lb 19,1). Przygotowaniami do ceremonii spalenia „czerwonej krowy” kieruje już jednak potem nie

2 Ph.P. Budd, Numbers (WBC 5), Waco 1984, s. 211; R.D. Cole, Numbers (NAC 3B), Nashville, s. 301.

3 R.D. Cole, Numbers..., s. 302.

4 E.D. Davies, Numbers (NCBC), Grand Rapids 1995, s. 194. 
Aaron, lecz jego „syn” - Eleazar (Lb 19,3-4). W kolejnych wierszach mowa jest już tylko o „anonimowym” kapłanie (Lb 19,6.7), a wreszcie również o udziale świeckich przy spalaniu (Lb 19,8) i zbieraniu popiołu (Lb 19,9-10a). Cała ceremonia dotyczy zarówno Izraelitów, jak i obcych przebywających pośród nich (Lb 19,10b). Z punktu widzenia kontekstualnego zatem tylko pozornie rozdział ten odstaje od reszty. Sekwencja osób zaangażowanych w przygotowanie popiołu, który potem posłuży do przygotowania „wody oczyszczenia” (Lb 19,17-22), stosowanej w usuwaniu nieczystości rytualnej zaciągniętej przez kontakt ze sferą śmierci (Lb 19,1116), sugeruje, że w tle pierwszej części perykopy stoi kwestia zmiany przywódców. Niezmiennie jednak nad materią natury kultowej nadzór pozostaje powierzony kręgom kapłańskim 5 . W wykonaniu późniejszego rytuału jednocześnie swój udział mają już jednak także świeccy. Początkowo - mimo wszystko - nie wiadomo, czemu służy rytuał spalenia czerwonej krowy. W Lb 19,11-22 zresztą nie ma potem mowy, że chodzi o popiół z „czerwonej krowy”. Wszystko odbywa się poza obozem Izraelitów (Lb 19,3). Wymogi dotyczące zwierzęcia są dość precyzyjne: ma być to krowa koloru czerwonego, bez skaz i niewykorzystana jeszcze do pracy. Należy ją zarżnąć w obecności kapłana Eleazara (Lb 19,3) i częścią jej krwi ma on następnie pokropić siedem razy w kierunku wejścia do Namiotu Spotkania (Lb 19,4). Reszta krwi, wraz ze skórą, mięsem i wnętrznościami oraz dodanymi do tego różnymi kawałkami drewna (cedr, hizop), związanymi karmazynowymi nićmi (lub materiałem), ma zostać spalona (Lb 19,5-6). W tym ostatnim przypadku można doszukiwać się jakiejś aluzji do przybytku i szat arcykapłana (por. Wj 36,8.35.37; 39,1-2), a w konsekwencji do treści Lb 18, gdzie mowa jest o roli kapłanów i lewitów ${ }^{6}$. Kolejna wzmianka o kapłanie (już nie Eleazarze) dotyczy obmycia przez niego swoich szat i dokonaniu rytualnej kąpieli, co umożliwia mu dopiero ponowne wejście do obozu. Niemniej mimo wszystko zostanie on nieczysty aż do wieczora. Podobnej procedurze muszą poddać się potem także inni uczestnicy rytuału. Dotyczy to tego, kto dokonywał spalenia krowy pod nadzorem Eleazara (Lb 19,8), i tego, kto następnie zebrał pozostały z niej popiół (Lb 19,9). Ten ostatni ma zostać zdeponowany w „czystym miejscu” (bemāqôm tāâhor) poza obozem i służyć przygotowaniu wspomnianej „wody oczyszczenia” (mê niddâ; Lb 19,9.13.20.21). Czy w istocie rdzeń $n d h$ należy tu łączyć z jego pierwotnym znaczeniem „menstruacja” (tak Jacob Milgrom7), czy raczej z sensem „wyłączyć”,

5 A. Leveen, „Lo we perish”. A Reading of Numbers 17,27-20,29, w: Torah and the Book of Numbers, red. C. Frevel, T. Pola, A. Schart, Tübingen 2013, s. 263.

6 A. Leveen, „Lo we perish”..., s. 263.

7 J. Milgrom, Numbers. The JPS Torah Commentary, Philadelphia-New York 1989, s. 445. 
„odłożyć na bok” (tak Adrianne Leveen"; por. w. 9: woda ma być przechowywana poza obozem), to kwestia sporna, chociaż to raczej ta druga interpretacja cieszy się dzisiaj większą popularnością, o czym będzie jeszcze mowa.

Tak przygotowana mikstura (popiół + woda) stanowi hațțāt. Ponownie czytelnik staje jednak przed dylematem interpretacyjnym. Czy słowo to rozumieć w sensie „ofiara za grzechy”, czy inaczej? Wszystko wszak odbywa się nie w świątyni, ale poza obozem. W kierunku sanktuarium (określanego wcześniej jako Namiot Spotkania; por. w. 4b) zwrócony ma być jedynie gest pokropienia krwią. Reszta krwi - inaczej niż w rytuale ofiarniczym - ma zostać potem jednak spalona wraz z pozostałymi częściami krowy. Ponadto dalej nie wiadomo, jakie są powody zaciągnięcia rytualnej nieczystości przez uczestników rytuału. On sam jest jednak na tyle ważny, że określa się go mianem „ustawy wieczystej” (lehuqqat ôlãm), obowiązującej zarówno synów Izraela, jak i obcych rezydentów przebywających pośród nich (Lb 19,10b). Tych pierwszych wspomina się już po raz trzeci (Lb 19,2.9.10b) $\mathrm{w}$ tej części perykopy. Czy zatem cała procedura jest odpowiedzią Boga na skargę Izraelitów, że nie mogą się zbliżać do "przybytku” (miškkan) (por. Lb 17,27-28)? Jest to bardziej prawdopodobne odniesienie kontekstualne niż bezpośrednie łączenie obecnego fragmentu perykopy z poprzednim rozdziałem?.

Dopiero druga część perykopy (Lb 19,11) zaczyna się od wskazania źródła rytualnej kontaminacji - fizyczny kontakt z ciałem zmarłego, który sprawia, że człowiek staje się zagrożeniem dla czystości sanktuarium (Lb 19,13; por. w. 20). Patrząc na wydarzenia opisane wcześniej (Lb 16-17: bunt i śmierć), zrozumiałe okazują się nie tylko przyczyny lamentu synów Izraela (Lb 17,27-28) ${ }^{10}$, ale i samo przeznaczenie obecnego rytuału przygotowującego środek zaradczy. Przeciwdziała on - nieuniknionym w życiu codziennym - kontaktom ze sferą śmierci.

W oczy rzuca się jednak to, że sam rytuał przygotowania „wody oczyszczenia” (Lb 19,1-10a) nie musiał wcale być pierwotnie powiązany z późniejszym jej przeznaczeniem (Lb 19,11-22) i klasyfikowany jako „ustawa wieczysta” (Lb 19,10a). Zauważyliśmy już, że w drugiej części perykopy nie wspomina się wprost (por. ww. 17.20.21), że jej składnikiem jest popiół z czerwonej krowy. Co więcej, nawet w opisie ostatecznego przeznaczenia tej wody nie podaje się szczegółów, jak przebiegać ma sam rytuał oczyszczenia wykonany z jej wykorzystaniem. Wspomina się jedynie, że w czasie „żałoby” (zwyczajowo trwała zwykle siedem dni)

8 A. Leveen, „Lo we perish”..., s. 263-264, przypis 25.

9 Tamże, s. 263.

10 Luźne nawiązanie do tych wierszy w Lb 19 sugeruje m.in. L. Schmidt, Das 4. Buch Mose. Numeri 10,11-36,13 (ATD 7,2), Göttingen 2004, s. 84. 
oczyszczenie tego, kto miał fizyczny kontakt z ciałem zmarłego, powinno być dokonane trzeciego dnia i potem raz jeszcze siódmego dnia (Lb 19,12). Kto tego nie dokona, bezcześci/kontaminuje "przybytek Jhwh” (w. 13: miškkan Jhwh). Kolejne wiersze wydają się poszerzać spektrum możliwych źródeł kontaminacji (Lb 19,1416). Już samo przebywanie w „namiocie” (be’ōhel), w którym ktoś umarł (w. 14), czy kontakt $\mathrm{z}$ otwartym naczyniem pozostającym $\mathrm{w}$ takim namiocie (w. 15) są pod tym względem kontaminacyjne. Podobne skutki mają potem również przypadki „na otwartym polu” (w. 16: 'al-ppenê haśśádeh; kontakt z zabitymi mieczem, kośćmi lub grobem). Mamy więc do czynienia z rytuałem pozwalającym na przygotowanie substancji „wyrywającej” członków wspólnoty synów Izraela (i obcych przebywających wśród nich) ze sfery śmierci, chroniącej zarazem czystość sanktuarium i umożliwiającej dostęp do niego (problem pojawiający się w Lb 17,27-28; por. Wj 12,22 i rolę "hizopu” w ochronie przed śmiercią) ${ }^{11}$. Ten ostatni aspekt obecny był również w poprzednim rozdziale (Lb 18), gdzie zaznacza się podział wewnętrzny sanktuarium $\mathrm{z}$ różnymi sferami przystępu i wejściem do Namiotu Spotkania, jako ostateczną granicą pomiędzy tym, co jest wewnątrz i na zewnątrz sanktuarium. Lb 19 skupia uwagę na „namiocie” pojedynczego Izraelity, ale przestrzennie ten namiot znajduje się w obozie synów Izraela, którego centrum stanowi Namiot Spotkania, z przybytkiem będącym jego najświętszą częścią. Innymi słowy, w Lb 18 w centrum uwagi są duchowi przywódcy, w Lb 19 zaś pozostały $\operatorname{lud}^{12}$. Ten związek obu rozdziałów na poziomie tematycznym przedłuża się również na Lb 20 na poziomie lingwistycznym (Lb 18; 20: rdzeń qdš). Co prawda w Lb 19 aspekt „świętości” nie jest tak wyraźnie zaznaczony, ale z Lb 20 rozdział ten łączy się z kolei poprzez rdzeń qbr (w Lb 19,16.18: jako rzeczownik „grób”; w Lb 20,1: jako czasownik „pochować/pogrzebać”). W Lb 19 istotną rolę w oczyszczeniu odgrywa „woda” (Lb 19,7-9.13.17-21). W Lb 20 woda również stanowi istotny element w perykopie (Lb 20,2.5.8.10.11.13.17.19.29); jest czymś, czego lud pożąda i czasowo odczuwa jej brak. Wydarzenia z tym związane ostatecznie przyczyniają się do śmierci Aarona i Mojżesza (Lb 20,12).

\section{Struktura}

W perykopie mamy wstęp (ww. 1-2a) i zakończenie (ww. 21b-22). W środku znajduje się opis rytuału uzyskania popiołu z czerwonej krowy i jego wykorzystania do sporządzenia wody oczyszczenia (ww. 2b-10). Następnie wskazane jest jej ogólne

11 A. Leveen, „Lo we perish”..., s. 265.

12 Tamże, s. 265: „In sum, chapters 18 and 19 offer a thorough response to the cries of he children of Israel with which we began. We shall see if it will be sufficient". 
(11-13) i uszczegółowione zastosowanie (ww. 14-16) do kontaminacji spowodowanej kontaktem ze sferą śmierci poprzez zwłoki zmarłych. Właściwa procedura zastosowania wody oczyszczenia opisana jest $w$ wierszach $17-19$. Ostatnie wiersze to groźba wyłączenia ze wspólnoty za brak wykonania rytuału czyszczenia (w. 20; por. w. 13) i klasyfikacja powyższego rytuału jako „ustawa wieczysta” (w. 21a; por. w. 10b).

Jak widać, mamy tu z jednej strony dwie procedury (przygotowanie popiołu i wody oczyszczenia i rytuał jej zastosowania) oraz powtarzające się elementy końcowe (ww. 13.20 i ww. 10b.21). Głównie z tych dwóch powodów badacze dzielą perykopę w różny sposób. Jedni widzą tu dwie części (1-10/11-22 lub 1-13/1422), a inni trzy (1-10/11-13/14-22). Zauważyliśmy już, że pomiędzy Lb 19,1-10 i Lb 19,11-22 jest wiele elementów różniących obie części perykopy i nie do końca są one ze sobą ściśle powiązane. Niemniej niektórzy badacze wskazują na możliwość takiego jej podziału i przyporządkowania poszczególnych elementów, aby dostrzec w kanonicznym kształcie tekstu strukturę symetryczną ${ }^{13}$.

Nie ulega wątpliwości, że w perykopie $\mathrm{w}$ istocie mamy dwie zasadnicze części. Pierwsza (ww. 1-10) zawiera zasady, według których ma zostać przygotowana odpowiednia woda oczyszczenia, a druga - reguły dotyczące jej zastosowania (ww. 11-22). Problem stanowi tu jednak nie tylko wspomniany już fakt, że w drugiej części brak jednoznacznych odniesień do części pierwszej, ale i to, że przy takim podziale w ogóle nie wiadomo, po co należy najpierw przygotować popiół, a z niego potem także wodę, zwaną ,wodą oczyszczenia”. Ten problem może rozwiązać włączenie wierszy 11-13 do pierwszej części perykopy. Wyraźnie widać, że $\mathrm{w}$ wierszach tych chodzi o przypadek ogólny (kontakt $\mathrm{z}$ ciałem zmarłego), a w kolejnych wierszach (ww. 14-16) o przypadki szczegółowe ${ }^{14}$. Takie „dopowiedzenie” umożliwia zatem symetryczny podział perykopy na dwie części (1-13/14-22). Mamy więc w obu częściach wstęp (A: ww. 1-2bA; A': 14a) zasady przygotowania substancji oczyszczającej (B: ww. 2bB-10) i odpowiadające tej sekcji przypadki szczególne do jej zastosowania (B': ww. 14b-16), a wreszcie przypadek ogólny: dotknięcie zmarłego (C: w. 11) i odpowiadający mu ogólny cel zastosowania substancji oczyszczającej (C’: w. 17). Na tym w zasadzie w przywoływanej tu propozycji strukturalnej symetria się kończy. W części pierwszej mamy bowiem sekcję D (w. 12a): oczyszczenie oraz sekcję E (ww. 12b-13): zapowiedź kary za

13 J. Milgrom, Numbers..., s. 437; Th. Staubli, Die Bücher Levitikus und Numeri (NSK.AT 3), Stuttgart 1996, s. 273.

14 B.A. Levine, Numbers 1-20 (AB 4a), New York 1993, s. 457-458; ponadto sekcja Lb 19,1-13 odnosi się do miśkān - „przybytku”, a sekcja Lb 19,14-22 do migdāš - „sanktuarium”. Podobnie R.D. Cole, Numbers..., s. 304. 
niewykonanie oczyszczenia, w drugim zaś panelu najpierw pojawia się sekcja E' (w. 20): kara, a po niej dopiero niemająca swego odpowiednika w sekcji D z poprzedniego panelu sekcja F (w. 21a), określona jako subskrypcja. Z tej „symetrycznej” struktury wyłącza się wreszcie także ww. 21b-22, zawierające „obserwacje uzupełniające".

Powyższa propozycja struktury jest zatem mało przekonująca i tworzona trochę na siłę. Lepsze wrażenie robią wspomniane już propozycje podziału dwu- lub trzyczęściowego. Podział ogólny na dwie części (ww. 1-10: przygotowanie; ww. 1122: zastosowanie) można uszczegółowić, dokonując podpodziału drugiej części. Mamy tu najpierw (ww. 11-12) przypadek ogólny i sankcję za brak wykonania czyszczenia (w. 13); przypadki szczególne (ww. 14-16), opis rytuału (ww. 17-19) z ponowną groźbą za brak jego wykonania (w. 20). Przy takim oddziale wyróżnić można jeszcze formułę wprowadzającą (ww. 1-2a: Mojżesz i Aaron) oraz konkluzję (w. 21-22) ${ }^{15}$.

\section{Status quaestionis w badaniach krytycznoliterackich}

W badaniach krytycznoliterackich od początku liczono się z tym, że perykopa może składać się z co najmniej dwóch części pochodzących od dwóch różnych autorów. Wskazywały na to przede wszystkim zauważane $\mathrm{w}$ niej różnice frazeologiczne ${ }^{16}$ oraz odmienne procedury w samym rytuale ${ }^{17}$. Hizop użyty do pokropienia (w. 18) był wcześniej spalany wraz z krową (w. 6). Osoby zaciągające nieczystość raz dokonują samooczyszczenia (ww. 11-12), a potem oczyszczającego pokropienia dokonuje wobec nich ktoś inny (w. 15). Kapłani wspominani jeszcze w pierwszej części perykopy (ww. 3-4.6-7) całkowicie znikają z pola widzenia w drugiej (ww. 14-22).

Uwagę badaczy zwracała od dawna także różnica pomiędzy bezosobową formułą wprowadzenia $z$ wiersza $2 a$ a charakterystycznym dla tekstów kapłańskich wprowadzeniem (Mojżesz $\rightarrow$ Aaron) $\mathrm{z}$ wierszy 1 i $2 \mathrm{~b}^{18}$. Potem zauważono - wspomniane już - przesunięcie odpowiedzialności za wykonanie przepisanego rytuału z Aarona na Eleazara (ww. 3-4) i wreszcie anonimowych kapłanów (ww. 6-7) oraz

15 Tego rodzaju podział, bardziej uszczegółowiony, proponują m.in. R.P. Knierim, G.W. Coats, Numbers (FOTL 4), Grand Rapids-Cambridge 2005, s. 221-222.

16 G. Gray, A Critical and Exegetical Commentary on Numbers (ICC), Edinburgh 1903, s. 254.

17 E.D. Davies, Numbers..., s. 195.

18 W wielu hebrajskich manuskryptach brakuje jednak imienia „Aaron” (w. 1), stąd badacze także i je uznają za późniejsze poszerzenie (por. Lb 5,1.11; 6,1; 15,1.17). Ponadto liczba pojedyncza adresata (w. 2b: „ty”) także sugeruje, że pierwotnym odbiorcą przepisów był sam tylko Mojżesz. Por. E.D. Davies, Numbers..., s. 196. 
laików (ww. 8-9). W dalszej części perykopy mam kolejne „powtórzenie”. Sposób obchodzenia się z materią rytualną jest tu inny, niż wymagałyby tego przepisy kultowe typowe dla $\mathrm{P}$. Opis pozostaje gdzieś na styku z tymi przepisami, ale na pewno nie jest z nimi tożsamy. Niemniej materia dotyczy sytuacji „wyższej konieczności”, klasyfikowanej, podobnie jak w tekstach P, jako țâmē' - „(rytualna) nieczystość”, a cały rytuał przygotowania substancji z niej oczyszczającej dokonuje się tu pod nadzorem kapłanów.

Zwraca uwagę podział zadań, w które zaangażowanych jest wiele różnych osób. Wszystko to konsoliduje wspólnotę wokół rytuału, który jednak sam w sobie jest nie do końca jasny. Tylko przygotowanie do niego wymaga kontroli i udziału ze strony kapłanów. Nadzorują oni to, czy samo zwierzę spełnia wymogi, potem także ubój krowy (ww. 2-3) i jej spalenie wraz z dodatkowymi materiałami (ww. 5-6). Wcześniej, tuż po uboju, kapłan wykonuje pokropienie krwią (w. 4). Samo zastosowanie wody oczyszczenia i prawdopodobnie (por. ww. 9-10a) także jej przygotowanie odbywa się już bez ich udziału ${ }^{19}$. Klasyfikacja procedury jako „prawo” (ww. 1-2a.10b) gwarantuje tu zatem niejako ten „oficjalny” nadzór nad całą procedurą przygotowania owej wody, co nie było wcale takie oczywiste w późniejszej tradycji rabinicznej (m.Parah; t.Parah $)^{20}$.

Czasowa kontaminacja, o której mowa (ww. 7.8.10a), związana jest ściśle z obserwacją końcową z wierszy 21b-22. Ze sposobu opisania całej procedury wynika, że kapłani są tu niejako oddelegowani do nadzorowania rytuału odbywającego się poza obrębem świątyni, ale mającego na celu jej ochronę przed kontaminacją. Widać tu wyraźny rytualny rygoryzm skierowany przeciwko kontaminacji zaciąganej już nie tylko przez kontakt ze zmarłymi oraz ich życiową energią (nepeš), ale $\mathrm{z}$ wszystkim, co może taki kontakt przedłużyć (np. otwarte naczynie w namiocie niedawno zmarłego). W samej obronie przed kontaminacją związaną ze sferą śmierci nie byłoby nic nowego, gdyby nie to, że tego rodzaju przepisy, jakie znajdujemy w Lb 19, nie mają swojej paraleli w innych miejscach, gdzie mowa jest Tamże. 
o podobnym problemie, a sam rytuał nie odpowiada znanym zwyczajom kultowym, zwłaszcza związanym z praktyką charakterystyczną dla środowiska kapłańskiego $^{21}$.

Od dawna znajdowano tu wiele kłopotliwych zwrotów i słów, które trudno było pogodzić z materiałem klasyfikowanym gdzie indziej jako $\mathrm{P}^{22}$. Może chodzić jednak o późniejszy tak zwany Sonderfall, gdyż w (post)kapłańskich przepisach rytualnych dotyczących czystości obozu pojawia się problem tych, którzy zaciągnęli nieczystość poprzez kontakt ze zmarłymi, ale brak wskazań, jak sobie z tym rodzajem nieuniknionej nieczystości dalej poradzić (por. Lb 5,2-4). Niemniej problem stanowi tu z kolei fakt, że w Lb 19, inaczej niż w Lb 5,2-4, nie ma mowy o konieczności oddalenia takich jednostek z obozu. Ponadto wspomniane w Lb 5,2 rodzaje nieczystości usuwane były w P poprzez „ofiary ekspiacyjne/za grzechy”23.

Kolejny element istotny dla krytyki literackiej to zmiana określeń. Najpierw mowa jest o „popiele” (w. 9: 'ēper), a potem o „prochu” (w. 17: “ăpar) ${ }^{24}$. Wyraźne, poszerzające powtórzenie treści w. $13 \mathrm{w}$ w. $20 \mathrm{w}$ odniesieniu do tych, którzy nie dokonaliby rytualnego oczyszczenia oraz powtórzenie statusu prawnego zawartych w perykopie przepisów (ww. 10b.21a) ${ }^{25}$. Za wtórne uważa się również zakończenie perykopy (ww. 21b-22). „Woda oczyszczenia” (mê niddâ) stanowi tu niemal trwały czynnik oczyszczający. Teraz bowiem nieczystość spowodowana kontaktem ze sferą śmierci trwa już nie do wieczora (ww. 7.8.10a), ale siedem dni (w. 11b.14b16a). Sama woda wydaje się stać tu na granicy tego, co czyste i nieczyste. Odgrywa

21 H. Seebass (Numeri..., s. 248) wylicza szereg „, anomalii” w stosunku do stylu typowego dla P. (1) perykopa nie zaczyna się od podania powodu, dla którego rytuał jest potrzebny. Od razu pojawia się opis rytuału, którego przeznaczenie nie zostaje wyjaśnione (dopiero w. 9b zmienia sytuację); (2) Zamiast rozwinąć wyjaśnienie, prawodawca zarządza oczyszczenie, które nie musi nawet $\mathrm{w}$ tym miejscu mieć nic wspólnego z kwestią kontaktu ze zmarłymi. Kiedy już o tym mowa (ww. 11-13), wskazania szokują magicznym charakterem; (3) Zanim jeszcze prawodawca wyjaśni do końca sam rytuał oczyszczenia, podaje już kolejne przykłady możliwej kontaminacji (ww. 14-16). Podana tu lista przypadków nie do końca pasuje do związanego z nią określenia „prawo" (w. 14a); (4) sam przebieg (opis; ww. 17-20) oczyszczenia jest potem relatywnie krótki.

22 A. Dillmann, Die Bücher Numeri, Deuteronomium und Josua (KeH AT 13), Leipzig $1886^{2}$, s. $104-$ 107; G. Gray, A Critical..., s. 241-243; H. Seebass, Numeri..., s. 243-244.

23 H. Seebass, Numeri..., s. 243.

24 Te zmianę można jednak wyjaśnić bez odwołania się do zasad krytyki literackiej. „Popiół” oznacza tu materię wyjściową do całej procedury, a „proch" materiał użytkowy w przygotowaniu mikstury (tak H. Seebass, Numeri..., 257). Miszna Parach 3.11b sugeruje proces dalszego rozdrobnienia grudek popiołu za pomocą moździerza. Być może zmiana ma na celu także chęć nawiązania do statusu zmarłych (tak S. Wefing, Beobachtungen zum Ritual mit der roten Kuh (Num 19,1-10a), „Zeitschrift für die alttestamentlische Wissenschaft” 93 (1981), s. 344).

$25 \mathrm{~W}$ ten sposób w. 20 tworzy link do ww. 10b-13, a w. 21-22 do ww. 7.8.10a. Por. S. Wefing, Beobachtungen..., s. 341-364; na ten temat także H. Seebass, Numeri..., s. 244-245. 
istotną rolę w procesie oczyszczenia w dniu trzecim i siódmym (ww. 12.19), a popryskanie nią powoduje jednostkowe skutki opisane słowem hatt $\bar{a} \bar{t}$ t.

Wielu badaczy widziało w perykopie trzy etapy rozwoju. Przypadek ogólny (10b.11-13), uznawany często za poszerzenie w stosunku do poprzedniej części perykopy, uzupełniony byłby opisem przypadków szczególnych kontaktów ze sferą śmierci, w „namiocie” (ww. 14-15) i „na polu” (w. 16), oraz praktycznymi instrukcjami zastosowania „wody oczyszczenia” (17-19).

Można do tego jednak podejść jeszcze inaczej. Wiersze 1-10/14-21a można uznać za tekst wyjściowy (niem. Grundbestand) oparty na jakimś pierwotnym Vorlage zawartym w wierszach 1-10, ww. 21b-22 i 10b-13 zaś za późniejsze dodat$\mathrm{ki}^{26}$. Prawne usytuowanie procedury (ww. 10b-13) w formie participium można uznać w istocie za „inny rodzaj literacki” niż procedurę z wierszy 1-10a. Sugeruje to potem również fakt, że o czerwonej krowie nie wspomina się po w. $13 \mathrm{~b}^{27}$ oraz enigmatyczne bô („w nim”; w. 12a), któremu brak precyzyjnego punktu odniesienia (np. do „wody oczyszczenia”).

W przypadku perykopy z Lb 19 daje się wreszcie zauważyć generalnie niezwykłość formy. Z tego powodu też uważano, że wymyka się ona kryteriom stosowanym zarówno przez krytykę literacką, jak i historię tradycji. Z jednej strony, nie do końca nawet daje się ją klasyfikować jako rodzaj prawa, a z drugiej - trudno było oprzeć się wrażeniu, że stoi za nią jakiś wcześniejszy (magiczny/apotropaiczny egzorcyzm), być może nawet zabobonny (tabu) rytuał, mający ustrzec wykonujących go przed jakimś zagrożeniem zewnętrznym ${ }^{28}$.

Wytropienie i odtworzenie historii redakcji perykopy Lb 19 nie jest zatem łatwe. Wiele sugeruje w niej, że można zakładać jakieś poszerzenie pierwotnej wersji rytuału lub tekstu. Detale jednak - jak wspomnieliśmy - wymykają się klasycznym zasadom analizy krytycznoliterackiej. Sercem perykopy na pewno jest część pierwsza (ww. 1-10a), ale i w jej przypadku, jak zauważyliśmy, trudno mówić o pierwotnej jedności, co widać choćby już w fakcie oscylowania pomiędzy 2. i 3. osobą liczby mnogiej (por. ww. 2-4), liczbie różnych osób zaangażowanych w procedury (od arcykapłana, przez kapłanów, po świeckich). Rozróżnienie i chronologia różnych

26 Tak L. Schmidt, Das 4. Buch Mose..., s. 84-86, z tym że Schmidt, w odróżnieniu od takich badaczy, jak R. Rendtorff, M. Noth czy E.W. Davies, nie uznaje w. 10b za integralne wprowadzenie do ww. 11-13.

27 J. de Vaulx, Les Nombres (SB), Paris 1972, s. 213-215.

28 J.M. Sprinkle, Red Heifer, w: Dictionary of the Old Testament. Pentateuch, red. T.D. Alexander, D.W. Baker, Downers Grove-Leicester 2003, s. 670. 
możliwych środowisk i tradycji „zaangażowanych” w tworzenie aktualnego kształtu perykopy jest jednak przedsięwzięciem wysoce spekulatywnym ${ }^{29}$.

Badacze w istocie prezentują różne podejścia do tych zagadnień i tym samym proponują różne modele wyjaśniające proces powstawania całej perykopy. Bez wchodzenia w detale, można je pogrupować w kilka zasadniczych tendencji. Część $\mathrm{z}$ nich widzi tu poszerzenie zakresu jakiejś pierwotnej procedury (ww. 1-10a $\rightarrow$ ww. 1-13) o szczegółowe instrukcje dotyczące możliwych sposobów zaciągnięcia nieczystości z powodu kontaktów ze sferą śmierci i konieczności wykonania rytuałów oczyszczających (ww. 14-22) ) $^{30}$ Inni z kolei uznają jedność perykopy w jej warstwie zasadniczej z kilkoma późniejszym uzupełnieniami dotyczącymi różnych

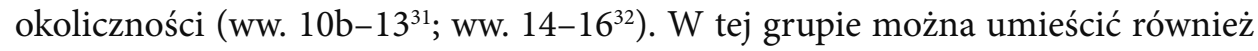
propozycję ${ }^{33}$, by $\mathrm{w}$ procedurze opisanej $\mathrm{w}$ Lb $19,1-10^{*}$ widzieć pozostałości jakiegoś pierwotnego kananejskiego rytuału o trudnym już dziś do określenia celu, który przejęty został jeszcze w formie bez udziału kapłanów ${ }^{34}$ (miałby on analogię w tak zwanej procedurze „ordaliów” z Lb 5,11-31!). Z czasem stracił swoje pierwotne znaczenie i został wykorzystany w procedurze oczyszczenia $\mathrm{z}$ rytualnej nieczystości zaciąganej przez kontakt ze zmarłymi. Wiersze 14-22 stanowiłyby zatem trzeci etap poszerzenia, na co wskazuje m.in. odmienny styl jurydyczny (w. 14a:

Część badaczy np. sugeruje, że sam rytuał oczyszczenia opisany w Lb 19 to w praktyce wypadkowa przepisów kapłańskich (P: ww. 17-19) i tych, pochodzących ze środowiska szkoły świętości (H: w. 12). Tak S.M. Olyan, Biblical Mourning. Ritual and Social Dimensions, Oxford 2004, s. 38 + przypis 27, ze wskazaniem na analizę I. Knohl, The Sanctuary of Silence. The Priestly Torah and the Holiness School, tłum. H.J. Feldman, P. Rodman, Minneapolis 1995, s. 93-94.

30 J. Wellhausen, Die Composition des Hexateuchs und der historischen Bücher des Alten Testaments, Berlin $1899^{3}$, s. 178; H. Holzinger, Numeri (KHC 4), Tübingen 1903, s. 78; R. Rendtorff, Die Gesetze in der Priesterschrift (FRLANT 44), Göttingen 1954, s. 65-66. Według tego ostatniego badacza pierwotny rytuał opisany jest $\mathrm{w}$ ww. 3b.5a.b.9a; za tym opowiada się również S. Wefing, $B e-$ obachtungen..., s. 354 (z tym że ten ostatni cały w. 9 uważa za wtórny).

31 M. Noth, Das vierte Buch Mose. Numeri (ATD 7), Göttingen 1966, s. 123, 125.

32 J. Scharbert, Numeri (NEB 27), Würzburg 1992, s. 76-77.

33 Tak cytowany wcześniej S. Wefing, Beobachtungen..., s. 346-364. Te propozycje oddziela również H. Seebass, Numeri..., s. 247. Autor ten nieco inaczej jednak rekonstruuje to pierwotne, kananejskie Vorlage. Zauważa (wskazując na podobne poglądy w: A. Dillmann, Die Bücher..., s. 104), że w perykopie są zlane w jedno co najmniej trzy motywy: (1) rytuał spalenia czerwonej krowy, by wytworzyć z tak uzyskanego popiołu „wodę oczyszczenia”; (2) powiązanie tego rytuału z Jhwh (motyw kapłanów), ale z obcym dla P rytuałem dotyczącym postępowania $\mathrm{z}$ krwią (w. 4b); (3) Tora (ww. 14-16).

$34 \mathrm{~W}$ tej propozycji np. uznaje się, że pierwotna procedura przygotowania „wody oczyszczenia” (ww. 2b3b.5.6 [bez odniesienia do kapłanów] 9a) została z czasem poddana pod nadzór kapłanów, a w końcu samego Eleazara; ww. 3a.4a. W ten sposób oryginalnie pogański rytuał włączony został w oficjalny kult Jhwh (tak R. de Vaux, Instytucje Starego Testamentu, t. I-II, Poznań 2004, s. $473-474$. 
„a to jest prawo...”), lista osób i rzeczy do czyszczenia oraz opis rytuału nie do końca pokrywający się z opisem procedury z ww. 1-10a. Jest wreszcie także pewna część egzegetów, która uważa, że oba modele nie muszą się wykluczać i można je ze sobą połączyćc ${ }^{35}$.

Dla pewnej części badaczy to, że rytuał nie jest przywoływany w innych źródłach i w praktyce nie wspomina się, aby był sprawowany gdziekolwiek indziej niż tyko w Jerozolimie, jest wystarczającym argumentem za jego archaicznością ${ }^{36}$. Słuszna jest jednak kontrargumentacja, że mamy wiele rytuałów wspominanych tylko w jednym miejscu w Biblii, a w obecnej perykopie mowa jest jedynie o tym, że należy pokropić krwią zabitej krowy „w kierunku” Namiotu Spotkania ${ }^{37}$. Jakkolwiek nie musi to oznaczać bezpośredniej bliskości (muzułmanie też modlą się „W kierunku/w stronę" Mekki, gdziekolwiek się znajdują), to konstrukcja gramatyczna wydaje się jednak sugerować bezpośrednią bliskość - o czym będzie jeszcze mowa. Inni ${ }^{38}$ wreszcie uważają, że nawet uznając wtórny charakter wierszy $21 \mathrm{~b}-$ 22 , resztę perykopy można potraktować jako tekst w miarę integralny literacko, a zmiany w słownictwie wyjaśnić logiką opisu całej procedury. W takim wypadku całość perykopy, nie wykluczając jednak wykorzystania jakiejś starszej procedury zachowanej w wierszach $2-10 \mathrm{a}^{39}$, można klasyfikować jako tekst postkapłański ${ }^{40}$.

35 J. Milgrom, The Paradoks of the Red Cow (Num 19), „Vetus Tesamentum” 31 (1981), s. 62-72; Ph.P. Budd, Numbers..., s. 211; B.A. Levine, Numbers 1-20..., s. 458.

36 J. Scharbert, Numeri..., s. 79.

37 W traktacie Miszna Parah (7.5; 7.6b; 9.6a) mowa jest o dużym transporcie „wody oczyszczenia” do Jafne, a nawet w kierunku Ezjon-Geber, w okolice zatoki Akaba. Zatem późniejsza tradycja rabiniczna także nie ograniczała zastosowania samego rytuału przygotowania i pokropienia tą wodą do Jerozolimy. Tosefta Parah (3.5) wspomina, że rytuał ten był praktykowany na wygnaniu w Babilonii. Według m.Parah 3.14; V.6; 7.4; 10.2 w czasach drugiej świątyni woda oczyszczenia dostępna była w 24 dystryktach poza Jerozolima i Judą. Niemniej w I w. po Chr. rytuał praktykowany był tylko w Palestynie, aby umożliwić udział w kulcie (Józef Flawiusz, Ant. 4,81; Bell. 5,227; ConAp. 2,104).

38 R. Schmitt, Magie im Alten Testament (AOAT 313), Münster 2004, s. 170, 175.

39 R.P. Knierim i G.W. Coats (Numbers..., s. 223) zwracają uwagę na trudności w rekonstrukcji warstw literackich, które można by przypisać klasycznym źródłom Pięcioksięgu. Z tego względu - jak słusznie sądzą - metody krytycznoliterackie są mało użyteczne przy próbach odtworzenia procesu powstania tej perykopy. Lepsze efekty daje tu metoda historii tradycji. Perykopa w ich ocenie nie może być jednak wyłącznie prostą artifcial composition, złożoną z elementów prawnych i kultowych. Rytuał poprzedzający przygotowanie „wody oczyszczenia” miał prawdopodobnie jakiś wcześniejszy etap magiczny lub apotropaiczny, pozostający pierwotnie poza kontrolą kręgów kapłańskich. Podobne założenia przyjmował nie tylko wskazany przez tych autorów I. Scheftelowitz (Das Opfer der roten Kuh (Num 19), „Zeitschrift für die alttestamentlische Wissenschaft” 39 (1921), s. 113-123), ale i wielu współczesnych badaczy, o czym później.

40 Tak cytowanym już R. Schmitt, Magie..., s. 170; a także R.P. Knierim, G.W. Coats, Numbers..., s. 224-225. 
Całość perykopy wydaje się w istocie łączyć w sobie elementy magiczne, jurydyczne i kultowe, wychodząc naprzeciw potrzebom oczyszczenia $\mathrm{z}$ kontaktu ze sferą śmierci także poza domeną oficjalnego kultu ${ }^{41}$.

Aktualne tendencje w sferze badań krytycznoliterackich wskazują, że tekst w swej finalnej, kanonicznej formie należy uznać za związany z późniejszą fazą w rozwoju tradycji kapłańskiej lub wręcz za postkapłański ${ }^{42}$. Obecny opis procedury podąża bowiem wyraźnie za kapłańską koncepcją hatța ${ }^{\prime} t$ - „ofiary (oczyszczającej) za grzechy"43, bazuje na związanych z nią procedurach, ale jednocześnie wyprowadza cały rytuał poza obręb świątyni, eliminując tym samym jej ofiarniczy charakter. W ten sposób nadaje się jednak zarazem pozakultowej ceremonii oficjalny charakter (obecność kapłanów). Być może zatem sam rytuał z czerwoną krową w istocie uznać należy, jak uważa wciąż wielu badaczy, za pierwotny i znacznie starszy od reszty perykopy. Intencja wypracowania obecnej wersji rytuału związana jest $\mathrm{z}$ wolą stworzenia procedury oczyszczenia dla świeckich, która odpowiadałaby procedurze kapłańskiego rytuału ofiarniczego hatța t. Z drugiej strony cały rytuał jednocześnie nie jest i być nie może ofiarą za grzechy w pełnym tego słowa znaczeniu. Umożliwia jedynie oczyszczenie z rytualnej nieczystości, kontaminującej innych członków społeczności (w. 22).

41 Na pierwotny, magiczny charakter całego zapożyczonego tu rytuału wskazywali m.in. A. Dillmann, Die Bücher..., s. 104; H. Holzinger, Numeri..., s. 78. M. Noth (Das vierte Buch..., s. 126) pisał: „[...] gehört zu den Überresten magischer Vorstellungen und Praxis [...]”; R. Schmitt (Magie..., s. 171): „Der magische Charakter des Rituals steht ausser Frage und wurde sowohl in der älteren als auch neueren Forschyng als 'survival' vorisraelitischer (kanaanäischer) Kultpraxis gewertet”. Podobnie inni współcześni badacze: J. Scharbert, Numeri..., s. 27, 76; J. Milgrom, The Paradoks..., s. 70; Ph.P. Budd, Numbers..., s. 214; S. Wefing Beobachtungen..., s. 362. Z kolei H. Seebass (Numeri..., s. 253) rozpatruje cały rytuał jako reakcję na zagrożenie jahwizmu ze strony kultu zmarłych we wczesnych czasach po wygnaniu babilońskim. W konsekwencji uznaje, że cały rytuał nie musi być wcale aż tak archaiczny.

42 G. Gray, A Critical..., s. 247; F. Crüsemann, The Torach. Theology and Social History of Old Testament Law, Edinburgh 1996, s. 362; C. Nihan, The Holiness Code between D and P. Some Comments on the Function and Significance of Leviticus 17-26 in the Composition of the Torah, w: Das Deuteronomium zwischen Pentateuch und Deuteronomistischem Geschichtswerk, red. E. Otto, R. Achenbach (FRLANT 206), Göttingen 2004, s. 118, przypis 167 (autor zalicza Lb 19 do tekstów związanych ze szkołą świętości - H, którą klasyfikuje jednocześnie jako etap redakcji post-P [s. 121]).

43 Oprócz w. 9 za takie przynależne do $\mathrm{P}$ (lub post-P) przepracowanie uznawano ww. 7.8.10.19.21b22. Por. R. Rendtorff, Das Gesetz...,s. 65-66; S. Wefing, Beobachtungen ..., s. 352-354. Na temat tego rodzaju propozycji por. także H. Seebass, Numeri..., s. 246-247. 


\section{Egzegeza}

\subsection{Klasyfikacja rytuału}

Formuła wstępna (w. 1) klasyfikuje całość jako mowę Boga skierowaną do Mojżesza i Aarona. Postać pierwszego arcykapłana (por. w. 3-4: Eleazar) - jak już zostało zauważone - jest prawdopodobnie wtórna (por. w. 2b: liczba pojedyncza: „przemów”). Zarówno objawienie via Mojżesz, jak i wspomniana postać arcykapłana to zapewne wkład autora (post)kapłańskiego w tę perykopę. Taki zabieg dodaje prestiżu dalszym przepisom i zarazem jest charakterystyczny dla $\mathrm{P}^{44}$. Formuła definiująca $z \bar{o}{ }^{\prime} t$ huqqat hattôrâ (w. 2aA), choć wydaje się z kolei nietypowa ${ }^{45}$, powraca jeszcze w Lb 31,21, a więc w tekście, którego autor zakłada obecne przepisy. $\mathrm{W}$ istocie zwykle stosowany jest zwrot $\mathrm{z}$ samym tylko słowem hattôrâ (por. Lb 27,11; 35,29). Z pomocą tego typu formuł deklaruje się na początku lub na końcu jakiejś perykopy (por. Wj 12,14) jurydyczny charakter danego przepisu lub instrukcji ${ }^{46}$. Chodzi prawdopodobnie o pierwotny, oryginalny tytuł tej perykopy, który łączy w jedno określenia z w. 21a (huqqat) i w. 14a (tôrâ). Podobny, choć tym razem prawdopodobnie wtórny charakter ma także formuła zawarta $\mathrm{w}$ konkluzji $\mathrm{z}$ wiersza 10b (lehuqqat 'ôlām; por. w. 21). Natomiast deklaracja z w. 9b (lemê niddâ ha 'tț't hiw') klasyfikuje cały przepis jako ceremonię kultową (por. Wj 12,11). Rzeczownik ha'tt't nie jest tu zawieszony „w powietrzu” i nie stanowi w żadnym wypadku początku nowej sekcji ${ }^{47}$, lecz opozycję wobec lemê niddâa ${ }^{48}$. Wskazuje na fakt, że „woda oczyszczenia” jest używana do rytualnej puryfikacji. W taki właśnie sposób stosowany jest czasownik jithatțā' ' w wierszach 12.20 i hitțt'ô w wierszu 19.

\subsection{Aktualne przeznaczenie rytuału}

Obecny kontekst rytuału przygotowania „wody oczyszczenia” związany jest z kontaktem ze sferą śmierci (ww. 11.14-16). Kontakt ten sprawia, że zaciąga się nieczystość rytualną. Wiele późnych tekstów klasyfikowanych jako $\mathrm{P} /$ post-P przewiduje możliwość oczyszczenia się z tego rodzaju nieczystości (por. Lb 5,2; 6,6-12; 9,6$10 ; 31,19 ; \mathrm{Kpł} 22,4-6)$. Po tego rodzaju kontaminacyjnych kontaktach ze zmarłymi zwykle wystarczało jednak samo obmycie wodą (Kpł 11,24-45; 22,4-7). W obecnym miejscu mamy jednak nie tylko poszerzenie listy spotykanych zagrożeń tego

H. Seebass, Numeri..., s. 255.

Tak B.A. Levine, Numbers 1-20..., s. 460.

R.P. Knierim, G.W. Coats, Numbers..., s. 224.

M. Noth, Das vierte Buch..., s. 124.

8 R.P. Knierim, G.W. Coats, Numbers..., s. 224. 
rodzaju. Dodatkowo pojawia się oryginalny i niepowtarzalny rytuał z wykorzystaniem, w celu oczyszczenia $\mathrm{z}$ tak zaciągniętej kontaminacji, popiołu z czerwonej krowy zmieszanego z żywą (to jest bieżącą) wodą. Ten sam rytuał zakłada się potem jeszcze w zaleceniach z Lb 31,21-24. Trzeba w tym miejscu zauważyć, że nie ma on paraleli $w$ innych starożytnych kulturach Bliskiego Wschodu. Jakieś dalekie podobieństwo można znaleźć jedynie w rzymskich ceremoniałach oczyszczających $^{49}$.

Jak już wcześniej zauważyliśmy, rytuał przygotowania „wody oczyszczenia” z domieszką popiołu z czerwonej krowy traktowany był przez część badaczy jako zapożyczenie jakiegoś wcześniejszego rytuału magicznego, czy nawet jako jakiś dawny egzorcyzm (tak m.in. M. Noth). Przypuszczenia takie nie są pozbawione podstaw, ale nie da się ich jednak przekonująco dowieść. Niewykluczone, że u podstaw całego rytuału w istocie leży jakieś dawne tabu. Sam opis procedury uzyskiwania popiołu (ww. 2b-10a), wyjąwszy wskazówki dotyczące kwestii czystości rytualnej, klasyfikację prawno-kultową i listę uczestników, robi bowiem wrażenie starożytnego rytuału wyjętego z nieznanego nam już pierwotnego Sitz im Leben (por. „gorzką wodę" z Lb 5,11-31; kwestię frędzli przy szatach z Lb 15,37-41), który został przepracowany $\mathrm{w}$ duchu późniejszych przepisów związanych $\mathrm{z}$ kwestią oczyszczenia $\mathrm{z}$ rytualnej nieczystości. $Z$ drugiej strony, wspomniana specyfika całego rytuału pozwala zarazem części badaczy widzieć tu bardziej przykład czysto teoretyczny, niemający potem jednak praktycznego zastosowania ${ }^{50}$. Niemniej Miszna sugeruje, że w późniejszym okresie rzadko, ale jednak praktykowano rytualny ubój czerwonej krowy (m.Parah 2.5). Ślad praktykowania tego rytuału znajdujemy być może również w tekstach z Qumran (1QS 3:4-10; por. potem także 4Q 276 1: 3-4; 4Q 277 1:6-7; 4Q 395 8; Hbr 9,13-14) $)^{51}$.

\subsection{Czerwona krowa}

Pytania o to, czemu krowa ma być akurat czerwona (w. 2b: pārâ ădummâ) i czy jej ubój ma charakter ofiarniczy - nurtują egzegetów od dawna ${ }^{52}$. Rabini (m.Parah 2.5) rozważali potem nawet kwestię tego, ile „nieczerwonych” włosów jest dopuszczalne, by krowa spełniła ten wymóg i była uznana za zwierzę „bez skazy” (por.

49 G. Gray, A Critical..., s. 247-249.

50 E.D. Davies, Numbers..., s. 193.

51 J. Bowman, Did the Qumran Sect Burn the Red Heifer?, „Revue de Qumran” 1 (1958), s. 73-84; J. Baumgarten, The Red Cow Purification Rites in Qumran Texts, „Journal of Jewish Studies” 46 (1995), s. 112-119; H.K. Harrington, Red Heifert, w: The New Interpreter's Dictionary of the Bible, red. K.D. Sakenfeld, Nashville 2009, s. 749-750, zwł. s. 749. 
w. 2aB: temîmâ $)^{53}$. W istocie o kolor włosia zapewne, a nie o kolor skóry chodzi również $\mathrm{w}$ tekście biblijnym ${ }^{54}$. Kwestia kolorystyki, czy raczej odcienia czerwieni (gniady, rudawy, brunatnoczerwony) ${ }^{55}$, o której mowa, podobnie jak symbolika tego koloru, to jednak problem trudny do rozstrzygnięcia (por. Rdz 25,30). Hebrajskie słowo pārâ oznacza w każdym razie „krowę” (LXX: damalis; por. Wulg. i Hbr 9,13), precyzując tym samym, że chodzi o zwierzę płci żeńskiej ${ }^{56}$. Słowo to nic nam już jednak nie mówi o jej wieku ${ }^{57}$, o którym można wnioskować $\mathrm{z}$ tego, że nie była ona jeszcze wykorzystana do pracy (nie nosiła jarzma; por. 1 Sm 6,7; potem także Pwt 21,3). Chodzi więc zapewne o młodą jałówkę. W innych miejscach równie dobrze może chodzić o starsze zwierzę (por. Rdz 41,2-4; 1 Sm 6,7). W traktacie m.Parah 1.1 mowa jest nawet o pięcioletniej krowie. Kolejny znak wyróżniający wspomnianą krowę to jej nieskazitelność w sensie fizycznym. Wymóg „bez skazy” doprecyzowuje się zaraz potem słowami: „która nie ma wady” (w. 2bA: 'ăšer 'ên-bāh mûm) (por. Kpł 22,21-25: ofiara składana przy okazji ślubów).

Nie mamy pewności co do tego, jakie symboliczne znaczenie ma kolor czerwony. Pozostając jednak przy ogólnym rozumieniu, że krowa miała nietypową, wręcz rzadką barwę, przypominającą przynajmniej kolor czerwony, trzeba mimo wszystko znaleźć odpowiedź na pytanie o symboliczne znaczenie tego koloru. Choć kontekst tego nie wskazuje wprost, można się domyślać, że kolor miał tu istotne znaczenie dla powodzenia całej procedury ${ }^{58}$. Pierwsze skojarzenia co do koloru to ogień (katarsis), w którym będzie spalona na popiół (por. Lb 19,5-6), lub jej krew jako instrument pacyfikujący skutki kontaktu ze śmierciąą. Jeśli chodzi o powiązanie z kolorem krwi, to być może barwa krowy antycypuje tu bardziej

53 „Two hairs of another colour as it body were sufficient to disqualify it”, cyt. za: J.H. Hertz, The Pentateuch and Haftorahs, London 19782, s. 652; przytaczam go za: R.D. Cole, Numbers..., s. 305.

54 Niemniej por. A. Brenner, Colour Terms in the Old Testament (JSOT.S 21), Sheffield 1982, s. $62-$ 65, zwł. s. 63.

55 A. Brenner, Colour..., s. 64-65. Podobnie w Za 1,8 słowo śeruqîn w odniesieniu do koni bywa rozumiane zarówno jako pstry, gniady lub ryżowo-czerwony, jasnoczerwony. Por. A. Brenner, Colour..., s. 114-115; KBL, t. II, s. 380, i dyskusję w: A. Wolters, Zechariah (HCOT), Leuven-Paris 2014 , s. $53-54$.

56 J. Milgrom (The Paradoks..., s. 65) sądzi, że samiec zarezerwowany był na ofiarę oczyszczającą od arcykapłana (Kpł 4,1-12; 16,11) lub od całej wspólnoty (Kpł 4,13-21), stąd dla jednostki przeznaczano krowę. Wybór płci może mieć jednak także inne znaczenie: krowa to potencjalna matka, zwierzę dające życie - tak S. Łach, Księga Liczb (PŚST II-2), Poznań-Warszawa 1970, s. 181. 
pokropienie krwią jako element procedury oczyszczenia o charakterze apotropaicznym (por. Lb 19,4) ${ }^{60}$.

Poza ubarwieniem krowy czerwony kolor mogły mieć także gałązki cedrowe i karmazyn. Czy w tym wypadku chodzi jednak o nawiązanie do koloru krwi użytej częściowo do pokropienia w kierunku wejścia do Namiotu Spotkania (w. 4), a potem spalonej wraz z resztą krowy poza obozem (w. 5)? Tego nie można być pewnym. Dodatki mogą mieć bowiem wyłącznie walor praktyczny - dodają masy do popiołu ${ }^{61}$. Jednak już sama krew w popiele może wzmacniać siłę oczyszczającą popiołu. Zdaniem niektórych badaczy w przypadku dodatków chodzi $\mathrm{w}$ istocie jedynie o symboliczne nawiązanie do kapłańskiego rytuału hațta ${ }^{2} t^{62}$. Skutki działania „wody oczyszczenia” są bowiem podobne do tych, jakie ma złożenie ofiary za grzechy w świątyni ${ }^{63}$. Sama krowa nie jest jednak typową materią ofiarniczą (por. $1 \mathrm{Sm}$ 6,7.14; $2 \mathrm{Sm}$ 6,13; potem jednak również Pwt 21,3-4), a miejsce dokonania uboju (poza świątynią, a nawet poza obozem; w. 3) także nie pozwala klasyfikować całej procedury jako ofiary. Niemniej wszystko odbywa się pod nadzorem kapłana. Czy chodzi zatem z jednej strony tylko o symboliczne nawiązanie do ofiary oczyszczenia, a z drugiej zarazem o realne wywołanie podobnych do niej oczyszczających skutków (por. Kpł 9; Hbr 9,11-14)? Choć sama krowa - jak wskazaliśmy - jest nietypowym zwierzęciem ofiarnym, może jednak nawiązywać symbolicznie do tradycji z 1 Sm 6, przy jednoczesnym wykluczeniu, że chodzi dosłownie o rodzaj ofiary za grzechy. Wykorzystanie samicy zwierzęcia ofiarniczego odpowiada przepisom z Kpł 4,27-35 dotyczącym ofiary hațtầ $t$ składanej za świeckich (zwł. w. 32; por. też Kpł 5,6). Przypomina również przepisy dotyczące

60 J.M. Sprinkle, Red Heifer ..., s. 669. Wcześniej podobne sugestie zob. A. Brenner, Colour..., s. 6465; J. Milgrom, Numbers..., s. 158.

61 J.M. Sprinkle, Red Heifer..., s. 669.

62 Wcześniejszą dyskusję i rozbieżne stanowiska w tej kwestii omawia krótko T.R. Ashley, The Book of Numbers (NICOT), Grand Rapids 1993, s. 365. Główny argument przeciwko ofiarniczej interpretacji rytuału to miejsce jego sprawowania - „poza obozem”. Niemniej z drugiej strony wiersze 9.17 sugerują jednak innym badaczom ofiarniczy charakter tego rytuału (T.R. Ashlej wskazuje tu komentarze N.H. Snitha, G.J. Wenhama, P.J. Budda i przede wszystkim artykuł J. Milgroma, The Paradox..., s. 86-95). Milgrom zauważa, że przepisy tu zawarte stoją blisko ceremoniału oczyszczenia z trądu (por. Kpł 14,1-9.49-53), a i ofiara z cielca charakterystyczna jest dla ofiar oczyszczających z grzechu (por. Wj 29,14; Kpl 4,11; 8,17; 16,27). Jednak tym razem spaleniu poddaje się także skórę (por. Kpł 4,11.20) i krew zwierzęcia, co nie pasuje do tego typu ofiar. Chyba że, jak sugeruje T.R. Ashley (The Book..., s. 365-366), krew sanowi tu główny czynnik oczyszczający w popiele. Nie można jej tym razem wylać na ołtarzu, więc wlewa się ją do reszty zabitej krowy spalanej w ogniu. 
oczyszczenia w przypadku nieodkrycia sprawcy zabójstwa (Pwt 21,1-9) ${ }^{64}$. Tam jednak wyraźne cały rytuał nie ma charakteru ofiarniczego, tu zaś choć też trudno go za taki uznać, to przynajmniej do niego na różne sposoby nawiązuje. Być może autor Lb 19 miał na uwadze starsze zasady z tego właśnie tekstu deuteronomistycznego i poddał je parakultowej transformacji. Nie można jednak wykazać jakiejś bezpośredniej zależności pomiędzy tymi dwoma tekstami ${ }^{65}$. Brak charakteru ofiarniczego przy jednoczesnym wskazaniu na skutki ceremonii przygotowania popiołu, „wody oczyszczenia” i jej oczyszczające zastosowanie może sugerować, że akcent położony na to, by krowa nie była używana wcześniej do pracy, ma tu w związku z tym jakieś symboliczne znaczenie ${ }^{66}$. Być może chodzi o to, że coś, co nie służyło jeszcze ludziom, wydaje się godniejsze Boga ${ }^{67}$.

Trzeba wreszcie zwrócić uwagę także na fakt, że to nie samo spalenie krowy ma charakter oczyszczający. Takie skutki uzyskuje dopiero popiół zmieszany z wodą, uzyskany po jej zabiciu i integralnym spaleniu poza obozem (por. Ez $28,18-19)^{68}$.

\subsection{Kapłani i świeccy}

Kapłani uczestniczący w rytuale to Aaron (w. 1), Eleazar (ww. 3-4) oraz inni bezimienni wykonawcy rytuału spalenia czerwonej krowy (ww. 6-7). Być może w tym ostatnim przypadku nadal chodzi o Eleazara, wspomnianego teraz tylko ogólnie jako kapłana ${ }^{69}$. Nie mamy co do tego jednak żadnej pewności. Aaron reprezentuje najwyższego kapłana. Postać Eleazara została wprowadzona być może po to, by symbolicznie ustrzec tego pierwszego przed kontaminacją związaną z udziałem

64 Por. zestawienie „paraleli” pomiędzy Lb 19,1-10 i Pwt 21,1-9 w: R.D. Cole, Numbers..., s. 307. Propozycja ta ma jednak kilka mankamentów. Krowa to nie to samo co czerwona krowa bez skaz; starsi w roli wykonawców rytuału to nie to samo co kapłani i świeccy, a i rola kapłanów-lewitów jest tu inna niż rola kapłanów w Lb 19.

65 R. Schmitt, Magie..., s. 175, 326-332. Na temat historii redakcji Pwt 21,1-9 zob. E. Otto, Deuteronomium 12,1-23,15 (HThKAT), Freiburg-Basel-Wien 2016, s. 1632-1634. Omówienie różnic pomiędzy Pwt 21 i Lb 19 także w: B.A. Levine, Numbers 1-20..., s. 471.

66 H. Seebass, Numeri..., s. 254.

67 Tak S. Łach, Ksiega Liczb..., s. 181 ze wskazaniem na Homer, Iliada 10.293; Odyseja 3.383; Owidiusz, Fasti 3,375-376; Wergiliusz, Eneida 6,38-39.

68 Na temat odniesień do tego tekstu zob. B.A. Levine, Numbers 1-20..., s. 471.

69 Tak sugeruje T.R. Ashley, The Book..., s. 366. 
w ceremonii (por. Kpł 19,7b i Kpł 21,10-12) ${ }^{70}$. Wówczas bezimienni kapłani muszą być uznani za osoby różne od Eleazara.

Całe zdarzenie ma miejsce poza obozem, a Eleazar jest jedynie świadkiem uboju (w. 3). Dokonuje się on „przed jego obliczem” (lepānājw). Wykonawca - podmiot działań - nie jest jednak określony (por. w. 3b) ${ }^{71}$. Miejsce również nie jest sprecyzowane. Znajduje się ono jednak poza obozem, gdyż cała ceremonia czyni uczestników nieczystymi (ww. 7-8.10), a chodzi o to, by ustrzec obóz przed kontaminacją. Według późniejszej tradycji miejscem ceremonii była Góra Oliwna (m.Parah 3.6). Tekst biblijny wydaje się wskazywać jedynie, że z miejsca tego widać było sanktuarium. Wtedy ceremonia odbywałaby się wyłącznie w bliskości Jerozolimy. Hebrajska konstrukcja 'el nôkah tłumaczona w sensie „w kierunku” jest jednak wyjątkowa. Inne zwroty ze słowem nôkah zakładają bezpośrednią obecność przed czymś (Rdz 25,21; Wj 26,35). Z tego powodu Sifre komentuje: „on [= kapłan] musi świadomie patrzeć na wejście do Przybytku, kiedy spryskuje krwią”. Ten komentarz odzwierciedla jednak późniejszą praktykę, akcentującą znaczenie obrania właściwego kierunku lub sposobu zorganizowania tego rytuału. Kontaminacyjny charakter kontaktu z sferą śmierci zakłada pewien dystans od sanktuarium, ale zarazem wizualne i geograficzne powiązanie całej ceremonii z tym miejscem, nawet jeśli potrzebny był duży dystans w stosunku do sanktuarium ${ }^{72}$.

Z tego głównie powodu - jak już zauważyliśmy - rytuał nie ma zatem raczej charakteru ofiarniczego. Palenie pozostałości z ofiar poza obozem miało miejsce wyłącznie po złożeniu wcześniej właściwej ofiary w świątyni (por. Kpł 4,11-12.21; 8,17; 9,11). Przy czym mięso żertwy ofiarnej palone było na ołtarzu. W obecnym miejscu nie ma o tym mowy. Ponadto wszystko to miało na celu oddalenie groźby kontaminacji, a nie jak obecnie - przywrócenia czystości rytualnej ${ }^{73}$. Po biernej asystencji przy uboju Eleazar ma do wykonania jedno istotne zadanie. Macza

70 Tak m.in. L. Schmidt, Das 4. Buch Mose..., s. 86. Badacz ten zakłada ponadto, że w oryginalnym Vorlage całą procedurę przeprowadzali świeccy i dokonywano jej poza miejscem zamieszkania. Kapłani w każdym razie tylko w drodze wyjątku (najbliżsi krewni) mogli uczestniczyć w obrzędach pogrzebowych (por. Kpl 21,1-4; Ez 44,25), a arcykapłan w ogóle nie mógł brać w nich udziału (Kpł 21,10-11).

71 H. Seebass, Numeri..., s. 255: być może należy instrukcję oddać przez bezosobowe „się”: „spali się" itd. lub bezosobowo: „zostanie zarżnięta” (tak. B.A. Levine, Numbers 1-20..., s. 461).

72 Tak B.A. Levine, Numbers 1-20..., s. 462.

73 Tak słusznie E.D. Davies, Numbers..., s. 197. 
swój palec we krwi krowy i kropi ${ }^{74}$ nią siedem razy w kierunku wejścia do Namiotu Spotkania (w. 4). Gest niewątpliwie nawiązuje symbolicznie do ofiarniczej roli krwi ${ }^{75}$. Demonstruje, że jest ona święta dla Jhwh. Siedmiokrotne pokropienie ma walor symboliczny. Tyle razy należy pokropić krwią tylko przy składaniu ofiar przebłagalnych za grzechy (Kpł 4,6.17; 16,14-15.19). To liczba ważna dla starożytnych Izraelitów (por. Kpł 4,6.17 $\rightarrow$ ofiara za grzech arcykapłana i całej wspólnoty ${ }^{76}$ ). Wyraża pełnię, kompletnośćc ${ }^{77}$. Po tej czynności cała krowa (skóra, mięso, krew i wnętrzności) zostaje „przed jego oczami” (leênājw) spalona (w. 5). Ta czynność, zwłaszcza palenie skóry, nie musi być nietypowa (por. Kpł 4,11-12). Spalanie „wszystkiego" znane jest w przypadku składania ofiar za grzechy (Kpł 4,11.21; 16,27; por. Wj 29,14; Kpł 8,7). Problem stanowi tu jedynie spalenie wnętrzności i krwi, która zwykle wylewana była na ołtarzu, a ściślej mówiąc, na jego rogach. Symbolicznie oznaczało to jej powrót do Boga. Niemniej jej spalenie w tym wypadku może wynikać $\mathrm{z}$ tego, że wszystko odbywa się poza obrębem sanktuarium ${ }^{78}$. „Wnętrzności” (hebr. pereš) ${ }^{79}$ to raczej zawartość żołądka, a nie jelit (ekskrementy, mierzwa). Te ostatnie uczyniłyby całość nieczystą. $Z$ tego względu właśnie nie palono tego nigdy na ołtarzu (por. Kpł 4,11; 8,17; 10,27 + potępienie w Ml 2,3).

Do ognia, w którym spala się krowę, anonimowy już kapłan ma dorzucić i spalić wraz z nią drewno cedrowe, hizop i karmazynowe nici (lub karmazynowy materiał). O rzeczach tych mowa jest jeszcze tylko raz, przy okazji wykonywania rytuału oczyszczenia z trądu i innych chorób skóry (Kpł 14,4.6.49.51-52), ale nie nakazuje się ich spalenia. Oczyszczenia $\mathrm{z}$ tych chorób dokonuje się ponadto w obozie, a nie poza nim. Zatem analogię stanowi jedynie pokropienie krwią.

W obecnym miejscu nie do końca jasne jest, czemu spalano akurat te rzeczy. Płonące drewno cedrowe mogło wydawać miły zapach. Hizop ma związek

74 Czasownik hizzâ ( $\rightarrow$ nzh) ma sens „obryzgiwać”, „kropić” (qal; 4 razy), „pokropić” (hifil; 20 razy (KBL, t. 1, s. 642). Pojawia się wyłącznie w tekstach klasyfikowanych jako kapłańskie. Por. W.K. Gilders, Blood Ritual in the Hebrew Bible. Meaning and Power, Baltimore-London 2004, s. 27.

75 S. Łach (Ksiegga Liczb..., s. 181-182) wskazuje (za C. Vriezen), że $n z h$ ma w Lb 19 dwa odmienne odcienie znaczeniowe (w. 4: „poświęcić”; ww. 18.19.21: „oczyścić”). Pokropienie wykonane w kierunku wejścia do Namiotu Spotkania nie ma jednak charakteru „poświęcającego”, lecz jednakowoż „oczyszczający” przestrzeń, jaka dzieli owe wejście od źródła potencjalnej kontaminacji.

76 Obu procedur nie da się jednak potraktować paralelnie. Por. H. Seebass, Numeri..., s. 255; przeciw T.R. Ashley, The Book..., s. 365.

77 Hasło: Siedem, w: M. Lurker, Słownik obrazów i symboli biblijnych, tłum. K. Romaniuk, Poznań 1989, s. 212-213.

78 Tak L. Schmidt, Das 4. Buch Mose..., s. 86.

79 KBL, t. 2, s. 60. 
z rytuałami pokropienia i oczyszczenia, symbolizuje życie, a karmazyn to barwa bliska czerwieni. Pewnej analogii do obecnego rytuału można doszukiwać się w starożytnej Babilonii, gdzie dodawano do świętej wody drewno cedrowe, cyprysowe i tamaryszkowe ze względu na ich aromat, wzmacniając - jak sądzono - moc tak przygotowanej mikstury ${ }^{80}$. Jednak obecnie chodzi o nieco inne dodatki, a ich identyfikacja wbrew pozorom nie jest wcale taka oczywista. Zwłaszcza w drugim i trzecim przypadku. Hebrajskie słowo 'ēzōp to bardziej origanum marjorana niż niewystępujący na terenach Palestyny - klasyczny grecki hizop (hyssopus officialis). Niemniej badacze mają problem z precyzyjnym określeniem rośliny, o której tu mowa (majeranek, szałwia, tymianek) ${ }^{81}$. Trudno zarazem orzec, czy jej zastosowanie ma tu w istocie na celu oczyszczenie (por. Ps 51,7), czy raczej wyłącznie zabezpieczenie przez kontaminacją (por. Wj 12,22; Kpł 14,4; Hbr 9,19).

Jeszcze większy problem jest z tłumaczeniem trzeciego z dodatków. Hebrajskie šenî tôlā 'at oddawane jest w polskich przekładach na różne sposoby: „karmazynowa nić” (BT; BE; tłum. interlinearne); „szkarłat” (BŚP), „karmazyn” (BWP), „wełna karmazynowa" (BP). W języku angielskim także w sensie scarlet stuff (RSV) ${ }^{82}$ lub scarled wood (NIV). Najstarsze sugestie leksykograficzne ${ }^{83}$ wskazują, że ,jest to oznaczenie purpurowych sznurków, opaski lub kawałka materiału do przewiązywania drzewa cedrowego i hizopu". Chodziłoby zatem o to, że dwa rodzaje dodatków (cedrowe drewno i hizop ${ }^{84}$ ) związane były za pomocą karmazynowego sznurka, nici lub materiału (tak m.in. m.Parah 3.11a). Być może zatem w tym wypadku chodziłoby również o symboliczne nawiązanie do koloru krowy.

Po wykonaniu tej czynności kapłan musi wyprać swoje szaty i dokonać rytualnego obmycia. Dopiero po tym wracał do obozu (por. Kpł 16,28: obrzęd przebłagania za grzechy), ale w tym wypadku pozostaje jeszcze nieczysty (!) aż do wieczora (w. 7; por. Kpł 15,5.7: w przypadku wycieków z ciała).

80 N.H. Snaith, Leviticus and Numbers (NCB), London 1967, s. 272.

81 R.K. Harrison, The Biblical Problem of Hyssop, „Evangelical Quarterly” 26 (1954), s. 218-224; B. Szczepanowicz, Atlas roślin biblijnych. Pochodzenie, miejsca w Biblii i symbolika, Kraków 2004, s. $164-166$.

82 DCH, t. 8, s. 504-505: ogólnie šānî oznacza „karmazyn, szkarłat”. W analizowanym tu zwrocie sugerowany jest sens „Crimson” (materiał), literalnie: „crimson of crimson” (Kpł 14,4.6.49.51.52; Lb 19,6; Syr 45,11).

83 KBL, t. 2, s. 562-563, zwł. s. 563.

84 Mało przekonująca jest jednak sugestia, że chodzi tu o największe i najmniejsze (krzaczaste) drzewo (por. $1 \mathrm{Krl}$ 5,13; tak S. Wefing, Beobachtungen..., s. 350-351). Zwłaszcza że to drugie nie rosło już w okresie drugiej świątyni. 
Świeccy uczestnicy rytuału angażowani są do spalenia krowy (w. 8a) i zebrania popiołu (w. 9a) ${ }^{85}$. Obaj, podobnie jak kapłan, muszą dokonać rytualnego oczyszczenia i zostają nieczyści aż do wieczora (ww. 8b.10a). To w tym miejscu badacze zauważają po raz pierwszy paradoks: proces przygotowania substancji mającej służyć oczyszczeniu powoduje zarazem kontaminację uczestników rytuału. Niemniej uczestnik odpowiedzialny za zebranie popiołu określany jest jako „mąż (rytualnie) czysty" ('î̌ țāhôr) ${ }^{86}$. Ma on zachować tę substancję poza obozem, „w czystym miejscu” (bemāqôm), by służyła potem przygotowaniu „wody oczyszczenia” (w. 9).

Pierwsza konkluzja po wykonaniu rytuału (w. 10b; por. w. 2a) odnosi go Izraelitów i obcych przebywających pośród nich. Woda oczyszczenia, trzymana w bliżej niesprecyzowanym miejscu, stanowi sposób na oczyszczenie pozwalające na dostęp do wspólnoty. Obcy nie mają tu niejako wyboru. Chcąc być członkami tej wspólnoty, muszą respektować obowiązujące w niej zasady rytualnej czystości. Niemniej rację ma Thimoty Ashley ${ }^{87}$, gdy akcentuje, że w. 10b nie stanowi zakończenia jakiejś pierwotnej jednostki literackiej, ale jedynie przejście od rytuału przygotowania popiołu i potem wody oczyszczenia do instrukcji na temat jej przeznaczenia (ww. 11-13). Chodzi zatem o wiersz pomostowy.

\subsection{Kontaminacja}

Nieczystość (ww. 7.8.10a) wymagająca oczyszczenia, która stanowi konsekwencję kontaktu z popiołem ze spalonej krowy, to - jak zauważyliśmy - pewnego rodzaju paradoks. Popiół służący przygotowaniu „wody oczyszczenia” (w. 9) jest jednocześnie substancją powodującą nieczystość u osób mających z nim kontakt ${ }^{88}$. Ceremonia jednak polega na zadaniu śmierci - krowa jest zarzynana i w całości spalana. Procedura ta, jak i popiół pozostały po jej wykonaniu należą do sfery śmierci ${ }^{89}$. Nie trzeba tu zatem doszukiwać się w tle tego rytuału pozostałości jakiegoś rodzaju „magii sympatycznej”ㅇ. Cała procedura określana jest wszak, wspo-

85 Tylko tu (ww. 9-10), jak już zauważyliśmy, używa się określenia 'ëper. Potem mowa jest o „prochu" (w. 17: "ăpar).

86 KBL, t. 1, s. 350.

87 T.R. Ashley, The Book..., s. 369; H. Seebass, Numeri..., s. 257.

88 Stąd tytuł artykułu J. Milgroma The Paradoks. Na ten temat także R. Schmitt, Magie..., s. 171172.

89 A. Dillmann, Die Bücher..., s. 107-108.

90 Określenie takie zaproponował J.G. Frazer, a przywołuje je jako klasyfikację Lb 19 B.A. Levine, Numbers 1-20..., s. 471: „[...] death rids the community of death! Ashes represent annihilation and are, therefore, effective when applied to person and objects defiled through contact with the dead. The mixture of ashes and living water had a primarily practical basis: in liquid form, this mixture could be applied to person and objects. The operative cultic principe is substitution". 
mnianym już, kultowym terminem hatțāt, który nie oznacza tu jednak „ofiary za grzech”, lecz „(parakultowe) oczyszczenie z grzechu”. Być może chodzi jedynie o dopasowanie jakiegoś rytuału pozostającego dotychczas poza kontrolą personelu świątynnego do ogólnie przyjętych norm. Akcentowanie obecności kapłanów podczas rytuału na początku perykopy (ww. 1-7) przy jednoczesnym udziale jednak także osób świeckich (ww. 8-9) może przemawiać za taką interpretacją. Część badaczy $\mathrm{z}$ tego powodu traktuje hatța ${ }^{\prime} t$ jako późniejszą glosę ${ }^{91}$. Jacob Milgrom ${ }^{92}$ doszukiwał się tu nawet pozostałości dawnego egzorcyzmu. Popiół ze spalonej krowy stanowił wcześniej - w jego opinii - substytut hatțā $t$. Dlatego potem został wprost określony kultowym terminem hatṭa $t$ ', a gest pokropienia krwią krowy w kierunku wejścia do Namiotu Spotkania dodatkowo łączył (jedynie symbolicznie!) całą ceremonię z kultowymi „ofiarami za grzechy”. Jak zauważał wspominany już Milgrom, to w tego typu ofiarach mowa jest o spalaniu resztek i oczyszczaniu się tych, którzy tego dokonują (por. Kpł 6,20-23; 16,28). Krew jest tu (zgodnie $\mathrm{z}$ koncepcją $\mathrm{P}$ odnośnie do hațtā t) nośnikiem nieczystości. Kontakt z nią może uczynić każdego nieczystym, nawet jeśli przed rozpoczęciem rytuału był klasyfikowany jako czysty. Innymi słowy, wyjaśnienie paradoksu łączy Milgrom z założeniem, że dawny, przedizraelski egzorcyzm powiązany został tu w zasadami dotyczącymi rytualnej nieczystości (Kpł 12-15). Pierwotnym czynnikiem prowadzącym do zaciągnięcia nieczystości byłyby zatem - według niego - „duchy zmarłych”. Nie ma tu jednak o nich mowy. Propozycja ta zakłada ponadto bardzo głęboką transformację „skutecznego” już rytuału. W podobnym kierunku idą propozycje łączące obecny rytuał z kultem zmarłych ${ }^{93}$. Niemniej w Lb 19 kazusy powodujące kontaminację są precyzyjnie wskazane (ww. 11-13.14-16). Powoduje ją kontakt ze sferą śmierci poprzez ciało i kości zmarłego oraz przestrzeń (namiot, znajdujące się w nim otwarte naczynia i grób), w której się ono znajduje. Wreszcie także krew - nośnik życia - nie jest jednocześnie nośnikiem nieczystości związanej ze śmiercią ${ }^{94}$. Niemniej samo założenie o rozwoju rytuału, czy raczej rozwoju znaczenia używanej w nim materii (popiół - woda oczyszczenia), od negatywnego do pozytywnego zastosowania może być słuszny. Wskazane przez Milgroma

91 H. Holzinger, Numeri..., s. 78; M. Noth, Das vierte Buch..., s. 124; J. Scharbert, Numeri..., s. 76; S. Wefing Beobachtungen..., s. 347-348.

92 The Paradox..., s. 90-94; Numbers..., s. 438-439; por. też D.P. Wright, Heifer, Red, ABD, t. 3, New York 1992, s. 115-116.

93 H. Holzinger, Numeri..., s. 78; B.A. Levine, Numbers 1-20..., s. 472-479; H. Seebass, Numeri..., s. 249-252.

94 A.I. Baumgart, The Paradox of the Red Heifer, „Vetus Testamentum” 43 (1993), s. 442-451, zw1. s. 443; R. Schmitt, Magie..., s. 172. 
związki z (post)kapłańskimi przepisami dotyczącymi ofiar oczyszczenia sugerują taką możliwość (por. Kpł 6,11.20: kontakt uświecający uczestnika).

Krew i popiół mogą wreszcie stanowić „pomost” umożliwiający przejście ze sfery śmierci do życia i jako takie stać na ich granicy. Reprezentują zatem jednocześnie obie sfery (por. Kpł 17,11) 95 $^{5}$. Jednak i takie założenie nie do końca jest słuszne. Krew reprezentuje życie - o czym była już mowa. Jako taka stanowi dar ofiarny dla Jhwh, który w kontakcie z sacrum znajduje swój najpełniejszy wyraz. Owe sacrum poprzez krew właśnie „kontaminuje”, to jest uświęca, uczestnika kultu, wymagając od niego „uświęcenia”, to jest oddzielenia od sfery profanum (por. Kpł 6,11.20; potem też 16,28$)^{96}$.

Nietrudno jednak zauważyć, że sposób obchodzenia się z substancją rytualną odbiega tu od zasad kultowych charakterystycznych dla środowiska kapłańskiego. Sami uczestnicy rytuału, choć działają w „słusznej sprawie”, stają się poprzez udział w rytuale țāmé ' rytualnie nieczystymi (Lb 19,7.8.10.21.22; por. też ww. 11.14.16.20 $)^{97}$.

\subsection{Woda oczyszczenia}

„Woda oczyszczenia” (mê niddâ) (w. 9b) to nazwa przyjęta w polskich tłumaczeniach. Patrząc na sugerowaną analogię ${ }^{98} \mathrm{z}$ mê hatțăt (Lb 8,7: „woda oczyszczenia” w BP; BŚP; „woda oczyszczająca” w BE; „woda przebłagania” w BT; BWP; „woda za grzech" w tłum. interlinearnym A. Kuśmirek), można sądzić, że tak jak w przywołanym przypadku chodzi o wodę usuwającą hatt usuwającą niddâ. Czym jest jednak owe niddâ? Znaczenie tego słowa jest sporne ${ }^{99}$. Etymologicznie łączy się je czasem z rdzeniem $n d h$ - „wyłączyć z grupy/oddalić" (niddâ - krwawienie menstruacyjne; por. też Kpł 12,2.5; 15,19-33; 18,19; Ez 22,10; 36,17; Za 13,1). Nazwę wody można wtedy tłumaczyć w sensie „(woda) oderwania/ odrazy/ skalania" (por. Kpł 20,21; Ezd 9,11). W tym znaczeniu woda, o której tu mowa (Lb 19,9.13.20; por. 31,23), stanowiąc pochodną sensu związanego z menstruacją ${ }^{100}$, może oznaczać również wodę „usunięcia (nieczystości)”. Taka

95 N. Kiuchi, The Puryfication Offering in the Priestly Literature: Its Meaning and Function (JSOT.S 56), Sheffield, s. 138-140; F.H. Gorman, The Ideology of Ritual: Space, Time, and Status in the Priestly Thelogy (JSOT.S 91), Sheffield 1990, s. 189; H. Seebass, Numeri..., s. 246. Krytyczne uwagi do tej teorii w: R. Schmitt, Magie..., s. 173.

96 R. Schmitt, Magie..., s. 173-174.

97 KBL, t. 1, s. 356-357.

98 T.R. Ashley, The Book..., s. 367.

99 KBL, t. 1, s. 622-633.

100 J. Milgrom, D.P. Wright, niddâ, TDOT, t. 9, Grand Rapids-Cambridge 1998, s. 232-234. 
propozycja nie pasuje jednak do konsekwencji w wypadku niezastosowania się do tego rodzaju oczyszczenia ${ }^{101}$.

Inna propozycja ${ }^{102}$, związana jednak nadal z powyższą etymologią, zakłada, że chodzi o rdzeń $n d h$, ale rozumiany jako wariant rdzenia $n z h$ - „rozpryskiwac”, „spryskiwać” (Kpł 6,20; 2 Krl 9,33: o krwi). Wtedy określenie wody można tłumaczyć w sensie „woda pokropienia/oczyszczenia” (ang. water of lustration/of sprin$k l i n g$ ). Oryginalnie - ponownie w odniesieniu do menstruacji - sens dopełnienia rozumiany byłby dosłownie jako „one who is spilling blood”. W ten sposób kobieta uznawana byłaby za nieczystą. Słowo $n d h$ samo z siebie nie oznacza jednak „nieczystości”.

Trzeba ponadto zauważyć, że pochodzenie etymologiczne od $n d h$ jest niepewne. Poza Księgą Liczb rdzeń ten opisuje przede wszystkim nieczystość. Analizowane tu słowo można potem równie dobrze łączyć z rdzeniem ndd II - „oddawać mocz”. Wtedy nazwa wody oznaczałaby również usunięcie nieczystości ${ }^{103}$. Rację mają więc chyba ci badacze, którzy sugerują tu ten ogólny i podstawowy sens: „wydalać, oddalać" lub - w pozytywnym znaczeniu - „oddzielić (od nieczystości)” ${ }^{104}$. W takim sensie słowo to być może pojawia się w Za 13,1: „źródło na oczyszczenie”. Wówczas jednak określenie tak przygotowanej wody kolejnym mianem hatt âa 't oznaczałoby, że słowo to ma sens „oczyszczenie (z grzechu)”, a nie „ofiara za grzech”"105. Ofiarniczy charakter ceremonii już zresztą odrzuciliśmy. Prawdą jest jednak, że hatța ${ }^{\prime} t$ to głównie termin techniczny na tak zwane ofiary za grzechy, czy lepiej powiedzieć: ofiary ekspiacyjne za grzechy. Tłumaczenie słowa hatț $\bar{a}^{t} t \mathrm{w}$ sensie „ofiara oczyszczająca za grzechy" nie do końca da się tu jednak zastosować. Kontaminacja zaciągana z powodu kontaktu z ciałem zmarłego nie implikuje grzechu, ale jedynie rytualną nieczystość. Jeśli już chcemy mówić o ofierze, to o ofierze oczyszczającej, a nie ofierze za grzech ${ }^{106}$. W obecnym wypadku słowo to jednak nie odnosi się do krowy, która zresztą nie była nawet złożona w ofierze, ale do popiołu uzyskanego po jej spaleniu i zmieszanego z żywą wodą. Sam akt spalenia ponadto opisany jest tu (w. 5a) słowem śárap, które często oznacza spalenie w sensie całkowitego zniszczenia czegoś (Am 2,1), czasem nawet także czegoś, co jest zarażone $(\mathrm{Kpł} 13,55)^{107}$.

101 B.A. Levine, Numbers 1-20..., s. 463.

102 Tamże, s. 464.

103 BDB, s. 622.

104 H. Seebass, Numeri..., s. 257.

105 Tamże: „Entsündigung Wasser”. Podobnie E.D. Davies, Numbers..., s. 199.

106 J.M. Sprinkle, Red Heifer..., s. 669.

107 KBL, t. 2, s. 376-377. 
Nigdy nie opisuje jednak spalania ofiary ${ }^{108}$. Takie techniczne rozumienie i tłumaczenie słowa hatțàt miałoby zatem także i z tego powodu mało sensu. Nawet jeśli uznać hatțā t’ za późniejszą glosę w obecnym miejscu (tak H. Holzinger, M. Noth), to wątpliwe jest, aby domniemany glosator z podanych powyżej względów chciał nadać tu taki techniczny, ofiarniczy sens całemu rytuałowi odbywającemu się nie tylko poza sanktuarium, ale nawet i poza obozem ${ }^{109}$.

O słuszności takiej interpretacji przekonuje nas także to, że oba występujące w obecnym miejscu słowa niddâ („nieczystość) i hatțā’t („grzech”) poza Lb 19,9 użyte są razem jeszcze tylko raz - we wspomnianym już tekście Za 13,1. W obu przypadkach chodzi o wodę wspomnianą w kontekście oczyszczenia. Zatem rytuał stojący w tle obu zastosowań należy rozumieć jako rytuał oczyszczenia ${ }^{110}$ (por. Kpł 15,19.20.33; 20,18; 2 Krn 29,5). Jako substancja płynna, woda dobrze nadaje się do zastosowania zarówno wobec osób, jak i rzeczy. Tak też rozumiały to starożytne tłumaczenia (por. LXX: hydōr rantismou; Wulg.: aqua aspersions - woda do pokropku; podobnie TgOn i TgJon: $m \hat{e}$ addejstâa). Jednak to nie słowo niddâ, lecz słowo hatțā t oznaczałoby tu ową nieczystośćc ${ }^{111}$, spowodowaną przez "grzech". Słowo hî̀ - „to”, pojawiające się za nim, może tu podkreślać jedynie siłę wyrazu. Skoro hatța 't zwykle oznacza ofiarę usuwającą grzech, tu zaś nieczystość spowodowaną kontaktem ze sferą śmierci, to sama woda powinna być rozumiana tak, jak oddają to polskie tłumaczenia - jako „woda oczyszczenia (z TEGO/TEJ grzechu/ nieczystości)".

\subsection{Przeznaczenie wody oczyszczenia}

Tajemniczy rytuał przygotowania „wody oczyszczenia” znajduje wyjaśnienie dopiero $\mathrm{w}$ drugiej części perykopy i związany jest tam z potrzebą usunięcia kontaminacji będącej następstwem kontaktu ze śmiercią, a ściślej mówiąc, z ciałem zmarłego. Izraelici, chcąc pozostać w relacji z Jhwh, muszą pamiętać, że jest On „Bogiem żywym”, „Bogiem życia” (por. Ps 42,3). Życie to coś, co odróżnia Boga Izraela od innych bogów. Dla przykładu Baal może być dotknięty śmiercią, a Jhwh nie $^{112}$. Śmierć pojmowana jest jednak nie tylko jako przeciwny biegun względem życia. Granica pomiędzy życiem i śmiercią nie jest w Starym Testamencie

108 H. Holzinger, Numeri..., s. 78; G. Gray, A Critical..., s. 252; S. Łach, Ksiega Liczb..., s. 182.

109 Tak słusznie E.D. Davies, Numbers..., s. 200.

110 M.J. Boda, The Book of Zechariah (NICOT), Grand Rapids-Cambridge 2016, s. 724 + przypis 8.

111 Por. B.A. Levine, Numbers 1-20..., s. 464: „water for sprinkling”, „water of lustration” „[...] applied to a menstruating woman, 'one who is spilling' blood. Such a woman was declared to be impure during her period, but is not the word niddāh that, by itself, connotes that impirity".

112 J. Goldingay, Old Testament Thelogy, t. 2: Israel's Faith, Downers Grove 2006, s. 26-28. 
precyzyjna i ostra. Śmierć - owszem - tu też oznacza koniec życia, ale rozumie się ją bardziej jako pewien proces i brak czegoś. Izraelici wierzyli, że nawet po śmierci człowiek nie przestaje istnieć. Przeciwnie, istnieje nadal, ale brak mu życia. Śmierć oznacza dla niego to, że rozchodzą się elementy stwórcze (por. Rdz 2,7). Proch wraca do ziemi, a oddech życia do Boga (Koh 12,7; por. Hi 34,14-15; Ps 146,4). Jak obrazowo ujmuje to autor Księgi Hioba: (człowiek) nagi wyszedł z łona matki (= ziemi) i nagi do niego powraca (Hi 1,21). Po dawnym żywym człowieku coś jednak pozostaje w zaświatach i można się z nim skontaktować chociażby poprzez praktykę nekromancji. O życiu człowieka decyduje zatem posiadanie przez niego boskiego nepeš/rûah (Ps 104,29; Rdz 35,18). Bóg sam jest zresztą określany jako rûah i to na poziomie owego rûah realizuje się relacja Bóg - człowiek ${ }^{113}$. Kontakt ze śmiercią jest wysoce niewłaściwy, oddala od Boga, uniemożliwia wręcz wstawianie się przed Nim i doświadczenie Jego obecności (Kpł 21; Lb 5,1-3; 19,11-22) ${ }^{114}$.

Stan nieczystości trwający siedem dni (w. 11b), o którym jest obecnie mowa, to zarazem zwyczajowy okres żałoby po zmarłym. Temat siedmiodniowej nieczystości powróci jeszcze w dalszej części instrukcji (ww. 14b.16a). Część badaczy, idąc śladem rabinicznej tradycji interpretacyjnej (Peszita rabbiego Kahane 4,2), przypisuje liczbie siedem szczególną rolę strukturalną w perykopie ${ }^{115}$ : (1) siedem razy wspomina się w niej o krowie i jej popiele (ww. 2.5.6.9bis.10.17); (2) siedem elementów zostaje spalonych: skóra, mięso, krew, wnętrzności, drewno cedrowe, hizop, karmazyn (ww. 5-6); (3) siedem razy następuje pokropienie (w. 4); (4) siedem rzeczy jest oczyszczanych (w.18); (5) siedem rzeczy ulega rytualnemu zanieczyszczeniu (ww. 14-16); (6) kapłani biorący udział w rytuale obmywają się siedem razy (ww. 4.6.7 [ze wskazaniem na Mojżesza, Aarona, Eleazara] 8.10.19.21; (7) siedem razy wspomina się kapłana (ww. 1 [Mojżesz i Aaron]; 3.4.6.7bis [Eleazar i inni kapłani]). Niewątpliwie liczba siedem odgrywa tu ważną rolę, choć cała proponowana struktura $(7 \times 7)$ jest raczej wtórną, późniejszą interpretacją całej perykopy ${ }^{116}$.

Oczyszczenie dokonuje się w trzecim i siódmym dniu (w. 12a). Takie dwukrotne zastosowanie wody może wskazywać na powagę sytuacji i ciężar gatunkowy kontaminacji ${ }^{117}$. Niewykonanie tej procedury oznacza pozostanie w stanie nieczy-

113 J. Lemański, Od Ducha Bożego/Jhwh do Ducha Świętego, w: Scripturae Lumen. Biblia i jej oddziatywanie, t. 8: Duch Święty, Tarnów 2016, s. 63-84.

114 J. Goldingay, Old Testament..., s. 638-640.

115 J. Milgrom, Numbers..., s. 437; Th. Staubli, Die Bücher..., s. 273; R. Schmitt, Magie ..., s. 170-171.

116 R. Schmitt (Magie..., s. 171) pisze: „[...] so scheint die rabbinische Deutung der Quadrierung der Sieben doch eher ein nachträglisches Konstrukt denne in konstitutives Element des Rtuals zu sein".

117 T.R. Ashley, The Book..., s. 371. 
stości (w. 12b) i stanowi zagrożenie dla wspólnoty. W wierszach 11-13 aż cztery razy mowa jest o „nieczystości” (țāmē') i tylko dwa razy o „czystości” (țāhôr). Dychotomię pomiędzy oboma tymi stanami dobrze podkreśla także chiazm w strukturze wiersza $12^{118}$.

Zasadniczy powód zaciągnięcia nieczystości, podany już w wierszu 11a, zostaje raz jeszcze powtórzony i zyskuje teraz dodatkowe uzasadnienie. Ten, kto nie dokona oczyszczenia, „bezcześci przybytek Jhwh” (w. 13a) i powinien zostać wyłączony ze wspólnoty (w. 13b; por. Lb 15,30-31). Treść w. 13 odpowiada treści w. 20, którą jednak zarazem $w$ pewny stopniu poszerza. Wiersz $13 \mathrm{bB}$ to być może pozostałość pierwotnej, starszej wersji wyroku ${ }^{119}$. Hebrajskie nikrat - „odciąć”, oryginalnie mogło oznaczać jedynie swego rodzaju ekskomunikę ${ }^{120}$, banicję, przymusową alienację względem wspólnoty klanowej. $Z$ czasem dopiero może coś więcej: utratę statusu społecznego, urzędu, a ostatecznie nawet śmierćn ${ }^{121}$. Powodem jest to, że bez rytualnego obmycia „jego nieczystość zostaje/trwa ( ôd; por. Rdz 8,22) w nim” i tym samym stanowi zagrożenie dla całej wspólnoty i jej relacji z Jhwh. Nowy element w tej części instrukcji (w. 13bA) to wskazanie, że oczyszczenie dokonuje się poprzez pokropienie (czasownik zrq często opisuje akt kultowy; Kpł 1,5; Ez 36,35; por. Lb 19,17-19).

Hebrajskie zwroty bemēt lekōl nepeš (ww. 11) i bemēt lenepeš häādām (w. 13) oznaczają tu ciało jakiegokolwiek zmarłego. Słowo nepeš ogólnie oznacza życie, pierwiastek ożywiający ${ }^{122}$. Tym, co zaskakuje egzegetów, jest jego połączenie ze sferą śmierci. Nie musi to być jednak aż tak dziwne, jeśli przyjmiemy możliwy dla niego sens „osoba” ${ }^{123}$. Chodziłoby zatem o sytuację kontaktu ze zwłokami jakiejkolwiek zmarłej osoby. Niewykluczone, że nepeš można tu również kojarzyć z mezopotamską koncepcją ețemmu - duchów zmarłych ${ }^{124}$, jednak przywołane wypowiedzi biblijne nie do końca się z nią pokrywają.

118 R.D. Cole, Numbers..., s. 310.

119 H. Seebass, Numeri..., s. 258.

120 J.M. Sprinkle, Red Heifer ..., s. 670.

121 B.A. Levine, Numbers 1-20..., s. 466. L. Schmidt (Das 4. Buch Mose..., s. 8, przypis 110) sugeruje, że „logicznym podmiotem” dla czasownika krt jest tu sam Jhwh. Być może ma rację i pierwotnie kara „wycięcia ze zgromadzenia” oznaczała karę z Jego strony, ale w obecnym kontekście zakłada się raczej działania samej wspólnoty.

122 Horst H. Seebass (Numeri..., s. 241) dowodzi, że tu u podstaw całej wypowiedzi leży sens „Individuum".

123 H.W. Wolff, Anthropologie des Alten Testaments, Gütersloh 2010, s. 43; C. Westermann, nepeš, Seele, THAT, t. 2, Gütersloh 1975; 1994', s. 71-96, zwł. 90-91.

124 Hasło: Gidim, w: Słownik mitologii Mezopotamii, red. J. Black, A. Green, Katowice 1998, s. 75. 
W Księdze Liczb znajdujemy w istocie kilka osobliwych przykładów kontaktu $\mathrm{z}$ nepeš 'ādām lub samym tylko nepeš, rozumianych jako coś, co przynależy już do sfery śmierci. Zwykle bowiem rozumie się, że pojęcia te użyte są $\mathrm{w}$ nich $\mathrm{w}$ sensie „Zwłoki zmarłej osoby”, które czynią człowieka nieczystym ${ }^{125}$. W Lb 9,6 czytamy: „Byli jednak mężowie, którzy byli nieczyści z powodu (kontaktu z/dotknięcia?) ludzkich zwłok (lenepeš 'ādām) i nie mogli w tym dniu obchodzić Paschy [...]”. Podobny sens można wyrazić również bez użycia słowa ādām, samym tylko słowem nepeš (Lb 5,2; 9,10). Dopiero przepisy z Lb 19,11.13 i te dotyczące kapłanów z Lb 21 pozwalają zrozumieć, o co tu w istocie chodzi. Zalecenie z Lb 19,11 brzmi: „Kto dotknie zmarłego (bemët), jakiejkolwiek osoby (lekōl nepeš), pozostanie nieczystym siedem dni”. Paralelne sformułowanie z Lb 19,13 dookreśla potem cały zwrot, stosując słowa nepeš 'ādām i dodając jeszcze słowa 'ăšer-jāmût - „która umarła”. W odniesieniu do kapłanów czytamy natomiast, co następuje: „I do żadnej zmarłej osoby (kôl-napšōt mêt) nie przystąpi ani z powodu swego ojca, ani z powodu swojej matki nie będzie czynił się nieczystym" (Kpł 21,11). Analogicznie sformułowane jest zalecenie skierowane do nazirejczyków (Lb 6,6). Problematyczne jest tu owo powiązanie czynnika oznaczającego życie (nepeš) ze sferą śmierci, czy ściślej rzecz ujmując, ze zwłokami zmarłego. Nie rozwiązuje się zadowalająco tego problemu tylko poprzez stwierdzenie, że chodzi o osobę. Zdaniem niektórych badaczy chodzi tu wręcz o coś więcej - o przekonanie, że zmarli (przejściowo i w ograniczonym czasie) pozostają w jakimś sensie jeszcze wśród żywych $^{126}$.W tym sensie zbliżenie się do zmarłego oznacza zarazem zbliżenie się do 'al-nepeš mèt. Oznacza to, że starożytni autorzy nie postrzegali momentu fizycznej śmierci jako wyznacznika ostrej granicy pomiędzy sferą żywych i umarłych. Co więcej, wyrażali przekonanie, że nepeš, jako niezwiązana z ciałem siła, może (jakiś czas?) istnieć oddzielnie od ciała, zanim powróci do Boga (por. Koh 12,7). Takie przekonanie - zdaniem Diethelma Mitchela - potwierdza także kolejna odsłona tematu z Lb 19,14-15, gdzie mowa jest o otwartym naczyniu w namiocie zmarłego, które także staje się nieczyste ${ }^{127}$. Brak w tym miejscu sprecyzowania czasu trwania

125 Por. J. van Oorschot, Lost in Translation, Regain by Exegesis. Npš alttestamentlischer Verwendung und Funktion, w: Anthropologie(n) des Alten Testaments, red. J. van Oorchot, A. Wagner, Leipzig 2015, s. 117-131, zwł. s. 125-127.

126 Por. D. Michel, Nepeš als Leichnam?, „Zeitschrift für Althebräistik” 7 (1994), s. 81-84, zwł. s. 83.

127 Zwrot kelî pātŭah - tłumaczony w sensie „otwarte naczynie” - oznacza pojemnik bez pokrywy ('ên-șāmî̀d) przymocowanej do niego sznurem (pātîll). 
owej nieczystości otwartego naczynia ${ }^{128}$ oraz instrukcji, co z tym w takiej sytuacji zrobić (por. w. 18). Zakłada się tu jednak, że nepeš, coś wyłącznie przynależnego do człowieka, nieoddzielnego od niego za życia, stanowiącego o tym, że ktoś żyje nadal w jego ciele lub obok niego pozostaje jeszcze jakiś czas po śmierci. Jak pisze wspomniany D. Michel ${ }^{129}$ : „Można oczywiście wyobrazić sobie, że po śmierci $n p \check{s}$ szuka sobie nowego «ciała», aby się do niego wślizgnąć - a (dostępne) było «tylko» to otwarte naczynie”. Takie przekonanie stanowi jednak wyłącznie domysł. Prawodawca może bowiem uważać jedynie, że „wyzwolone” z ciała nepeš, zanim opuści ostatecznie namiot zmarłego, zanieczyszcza wszystkie obecne w nim sprzęty, w tym otwarte naczynie. Może za tym uszczegółowieniem stoi jakieś pierwotne, demoniczne tabu ${ }^{130}$, choć ten aspekt wydaje się tu mniej prawdopodobny. Stary Testament generalnie nie zawiera żadnych wskazań czy rytuałów antydemonicznych. Jeśli takie demoniczne obawy funkcjonowały w popularnej pobożności (por. Księga Tobiasza), to zawsze wystarczającą obroną był tradycyjny kult Jhwh i ufność w Jego protekcyjną moc.

Lb 19,14-16 to w istocie uszczegółowienie możliwych powodów zaciągnięcia nieczystości trwającej siedem dni. Część dotyczy sytuacji człowieka zmarłego w namiocie (w. 14a; LXX: „w domu”). Kontaminujące jest już samo wejście do takiego namiotu. Nie precyzuje się jednak, czy chodzi zarazem o miejsce, w którym odbywały się rytuały żałobne ${ }^{131}$. Zaznacza się natomiast, że niebezpieczne pod tym względem jest także, wspomniane już, otwarte naczynie, które się w nim znajduje (w. 15). Chodzi zatem o ostrzeżenie nie tylko przez fizycznym kontaktem ze zwłokami, ale wręcz i zagrożenie płynące z samej bliskości ciała zmarłego ${ }^{132}$.

Druga zaś część dotyczy sytuacji „na polu”, a więc na otwartej przestrzeni. Tu kontaminujące jest dotkniecie zabitego mieczem, zmarłego, jego kości lub grobu (w. 16). Jak zauważa Horst Seebass ${ }^{133}$, uderzające w tym ostatnim wierszu jest to, że

128 Wiersz 19: oczyszczające z nieczystości pokropienie trzeciego i siódmego dnia dotyczy wyłącznie osób. Według 11Q19 49,8-9, czyli tak zwany Zwój świątyni, a taka nieczystość była permanentna i naczynie należało zniszczyć (por. Kpł 11,32-34).

129 D. Michel, Nepeš..., s. 83. Na ten temat zob. także J. Lemański, O właściwe rozumienie greckiego pojęcia „dusza” (psychē) stosowanego w Starym Testamencie”, w: Problem psychofizyczny, czyli pytanie o istnienie i naturę duszy, red. J. Lemański, P. Goniszewski, Szczecin 2019, s. 11-64, zwł. s. $48-49$.

130 Tak sugeruje H. Seebass, Numeri..., s. 259.

131 Por. Koh 7,2: bêt 'ēbel - „dom żałoby”; Jr 16,5: bêt marzēah - „dom zgromadzeń” (tu w celach przeżycia wspólnej żałoby); por. G. Fischer, Jeremia 1-25 (HThKAT), Freiburg-Basel-Wien 2005, s. 523-524.

132 S.M. Olyan, Biblical Mourning..., s. 36.

133 Numeri..., s. 251-252, 259-260. 
obok pojedynczych odniesień do grobów i kości pojawia się także wyszczególnienie poległych od miecza. Ci ostatni objęci byli już wskazaniem ogólnym - zmarli (por. w. 13). W jego opinii tym razem może chodzić jednak o nawiązanie do kultu bohaterów (niem. Heroenkult) - kolektywnej heroizacji poległych podczas wojny (por. Rdz 6,4; Lb 13,33). Groby to dobre miejsca na tego rodzaju kult (por. też Ez 43,7) ${ }^{134}$. Być może jednak reguły z Lb 19 - zauważa ten sam badacz - mają za zadanie jedynie ogólnie uregulować kwestie kontaktów ze sferą/ światem śmierci, zanim jeszcze pojawił się kultu zmarłych, praktykowany w grobach, i zanim jeszcze podane tu zasady zaczęły dotyczyć uczestników takiego kultu (por. Pwt 26,14; Iz 65,[3-]4; Ps 106,28). Tych kwestii nie możemy już dziś definitywnie rozstrzygnąć. Niemniej Lb 19 bez wątpienia ma na uwadze, że kontaminacja tego rodzaju zawsze wyklucza człowieka z udziału we wspólnocie i praktykowanym przez nią kulcie (por. Lb 21,1-4: zakaz udziału arcykapłana w rytach żałobnych). Zaraz potem więc opisuje się tu wyrafinowane rytuały oczyszczające.

\subsection{Instrukcje wykonawcze}

Prawodawca podaje w końcu instrukcje dotyczące sposobu użycia „wody oczyszczenia" (ww. 17-19/20-22). Chodzi o wyraźne zdefiniowanie granic pomiędzy życiem i śmiercią i tym samym polaryzację uniwersum ${ }^{135}$. Procedury związane ze zmarłymi zawsze mają charakter rozłączny w stosunku do wspólnoty wyznawców Boga żywego. Dlatego odbywają się w oddaleniu od sanktuarium i obozu. Tymczasem większość (post)kapłańskich rytuałów odbywała się "przed Jhwh” (lipne $J h w h$ ), tzn. w obrębie sanktuarium (por. Kpł 4,1-21; 13-14; 16). W tym kontekście opisany obecnie rytuał bez wątpienia jest unikatowy.

Popiół należy zalać żywą, to jest źródlaną, wodą (w. 17). Zachodzi tu sygnalizowana już zmiana słownictwa. Słowo ‘ěper - „popiół” zostaje zastąpione teraz słowem “ăpar - „proch”. Może chodzić jedynie o potrzebę większego rozdrobnienia grudek popiołu (por. Rdz 18,27), aby ułatwić jego zmieszanie z wodą, lub wskazuje się wyłącznie na to, że popiół ma konsystencję jak proch ${ }^{136}$. $Z$ drugiej strony nie można tu wykluczyć chęci symbolicznego nawiązania do stanu zmarłych (por. $\operatorname{Rdz} 3,19)$ lub, co wydaje się jeszcze bardziej prawdopodobne w obecnym kontekście, wskazania na całkowite unicestwienie czerwonej krowy ${ }^{137}$.

$134 \mathrm{Na}$ temat możliwych odniesień w tym wierszu do kultu zmarłych królów zob. D.I. Block, The Book of Ezechiel. Chapters 25-48 (NICOT), Grand Rapids-Cambridge 1998, s. 584-585.

135 T. Frymer-Kensky, Pollution and Purification in Biblical Israel, w: The Word of the Lord Shall Go Forth, red. C.L. Meyers, M. O'Connor, Winona Lake 1983, s. 399-414.

136 B.A. Levine, Numbers 1-20..., s. 468.

137 Tamże. 
Następnie „mąż czysty” ${ }^{138}$ zanurzy w niej hizop i dokonuje pokropienia namiotu, jego wyposażenia i tego, kto dotknął kości, zabitego, zmarłego lub grobu (w. 18). Akcent pada na sposób wykonania pokropienia. Aż cztery razy powtórzona jest tu partykuła 'al. Pokropienie ma być zatem dokonane „na”, „nad”, „naprzeciw” czy "przy”? ${ }^{139}$ Najbardziej prawdopodobne wydają się dwie pierwsze możliwości. Jednak analogia z pokropieniem krwią może sugerować także wykonanie czegoś „naprzeciw; w kierunku do; ku” ${ }^{140}$. Ten rytuał ma w każdym razie zostać powtórzony dwa razy, w trzecim i siódmym dniu (w. 19a). Egzegeci zwracają uwagę na zmianę rdzenia czasownikowego opisującego akt pokropienia. Wcześniej była mowa o zōraq (por. Lb 19,13.20: „zostać pokropionym” = pual lub qal passivum), obecnie o hizzâ (= nzh) - „pokropić, spryskać” (Lb 19,18.19; por. potem też ww. 4.21). Rozłożenie zastosowania obu słów jest wyraźnie chiastyczne. Zmiana słownictwa, jak wskazuje powyższy układ strukturalny, oraz greckie tłumaczenie obu słów z pomocą jednego tylko czasownika perirrantizō/perirrainō może zatem oznaczać, że nie chodzi tu o dwa odmienne rytuały pokropienia ${ }^{141}$. Rzecz idzie raczej o akcent położony na konieczność wykonania tego rytuału (ww. 13.20), dotyczącego osób i rzeczy (w. 18) oraz powtórzonego pokropienia trzeciego i siódmego dnia (w. 19: dotyczy tylko osób!).

Następnie "mąż nieczysty” wypierze swoje szaty, obmyje się i wieczorem siódmego dnia będzie czysty (w. 19b). Choć jak zauważyliśmy powyżej, pokropienie dotyczy także namiotu i sprzętów, to potem mowa jest tylko o oczyszczeniu uczestników rytuału. Nie ma więc pewności, czy rozciąga się ono również na wszystko, co uległo kontaminacji (por. ww. 14-15). Każdy, kto nie dokona takiego oczyszczenia, zostaje nieczysty, zbezcześcił Przybytek Jhwh ('et-miqdaš Jhwh; por. w. 13: 'et-miškan Jhwh) i ma zostać wyłączony ze zgromadzenia (w. 20: krt + mittôk haqqāhāl; por. w. 13b: krt + hannepeš hahiw' mijjiśrāēl). Rytualna czystość sanktuarium stanowi warunek owocnego trwania wzajemnych relacji pomiędzy Jhwh i Izraelem. Zwraca uwagę ponownie zmiana słownictwa zachodząca pomiędzy w. 13 i w. 20. Zamiast mijjiśräāel - „spośród Izraela” - pojawia się słowo „zgromadzenie" (qāhāl; por. Lb 14,5; 15,15; 16,23; 17,12; 20,6; nie „wspólnota” - ‘ēdâ, słowo użyte w Księdze Liczb 81 razy), a kapłański termin miškan - „przybytek” (por. w. 13) zastępuje teraz słowo „sanktuarium”, miqdaš. Nie musi to oznaczać, że

138 Określenie wskazuje funkcję, którą ktoś pełni podczas rytuału. Zob. H. Seebass, Numeri..., s. 260. 139 KBL, t. 1, s. 770-772.

$140 \mathrm{~W}$ obu wypadkach mamy - co prawda - odmienne partykuły (odpowiednio 'el i 'al), ale druga z nich może występować w sensie analogicznym do pierwszej. Por. KBL, t. 1, s. 771, nr 6.

141 Tak uważał T.R. Ashley (The Book..., s. 372); przeciwnego zdania jest R.D. Cole (Numbers..., s. 313). 
mamy do czynienia $\mathrm{z}$ innym redaktorem tekstu. Zmiana tego rodzaju sprawia raczej wrażenie, że autor biblijny chce tym razem zaakcentować antyczny charakter tej zasady ${ }^{142}$.

Konkluzja z w. 21 a odnosi się do instrukcji z ww. 17-20 i - jak zostało wcześniej wspomniane - swoje dopełnienie znajduje w tytule z w. 2, który łączy ją z tytułem z w. 14. Kolejne wiersze (ww. 21b-22) to uzupełnienie instrukcji dotyczących sposobu wykonania całej procedury oczyszczenia.

Osoba - mąż czysty - sprawująca rytuał również musi wyprać swoje szaty, a każdy, kto styka się z wodą oczyszczenia, pozostaje nieczysty aż do wieczora (w. 21b). Podobnie też każdy i wszystko, co ma styczność z osobą nieczystą, pozostaje nieczyste aż do wieczora (w. 22; por. Kpł 11,27-28).

\section{Wnioski}

Jak słusznie zauważał to już Gerhard von $\operatorname{Rad}^{143}$, Lb 19 to przykład spojrzenia na śmierć od strony kultu.

[...] Wszystko, co jest pozbawione życia, co umarło, przedstawia najwyższy stopień nieczystości (Lb 9,6; 19,11.16.18; 31,19 o śmierci ludzi; Kpł 11,24-28 itp. o śmierci zwierząt). Nieczystość wychodząca od tego, co nieżywe, spada nie tylko na ludzi, lecz także na rzeczy znajdujące się w zasięgu nieżywego (Kpł 11,33nn), co więcej, ktoś, kto sam stał się nieczysty, może nawet przenieść ją jeszcze dalej, poprzez dotyk (Lb 19,22). Przez tę nieczystość śmierci zagrożone były zwłaszcza osoby znajdujące się w stadium zaawansowanej świętości: kapłani i nazirejczycy (Kpł 21,1nn., 10nn.; Lb 6,6 nn.) [...]. Nieczystość spowodowana kontaktem ze zmarłym jest co do stopnia wyższa od innych nieczystości, nie można dlatego - jak w przypadku nieczystości seksualnych - usunąć jej poprzez obmycie wodą; do tego potrzebna była specjalna woda oczyszczająca, którą przygotowywano przy użyciu popiołu z czerwonej krowy (Lb 19,1 nn. $)^{144}$.

Bóg Izraela jest Bogiem żywych, a nie umarłych (por. Mk 12,26-27). Sfera śmierci nawet i bez tego fundamentalnego przekonania Jego wyznawców budziła zawsze jakiś lęk i poczucie niepewności. Choć wyobrażenia samych Izraelitów $\mathrm{w}$ tej materii nie były aż tak pesymistyczne, jak innych ludów semickich ${ }^{145}$, to i tak samą śmierć rozumiano jako oddalenie, czy wręcz zerwanie z Bogiem czczonym za życia. Choć człowiek według tych wyobrażeń „nie całkiem umierał”, to

142 B.A. Levine, Numbers 1-20..., s. 468; H. Seebass, Numeri..., s. 261.

143 Teologia Starego Testamentu, tłum. B. Widła, Warszawa 1986, s. 219.

144 Tamże.

145 Por. J. Lemański, Hebrajski szeol na tle wyobrażeń eschatologicznych sąsiednich kultur, „Scripta Biblica et Orientalia" 3 (2011), s. 67-97. 
niepewność co do sfery post mortem stanowiła o tym, że śmierć zawsze otoczona była jakimś tabu, a kontakt z nią rozumiano jako swoiste „Zarażenie się śmiercią”, powodujące automatycznie zaciągnięcie nieczystości rytualnej. Ta z kolei nie tylko uniemożliwiała pobyt we wspólnocie czczącej Jhwh - „Boga żywego” (Ps 42,3) ale wręcz zagrażała dalszą kontaminacją jej i chronionej przez nią świątyni.

Poglądy te to nie element poboczny w religii Izraela. Chodzi w nich bezwzględnie o fundamentalny element światopoglądowy i kosmologiczny. Bóg jest „w górze”, a świat zmarłych „na dole”. Specyficzny charakter rytuału z Lb 19 wnosi w te wyobrażenia pewne novum. Mobilizuje wszystkie siły, jakie drzemią we wspólnocie, do obrony przed taką nieuniknioną kontaminacją i oddaleniem od Boga, źródła życia.

Ludzie rodzą się i umierają. Krewni dbają o to, by godnie pochować swoich zmarłych, i już choćby z tego faktu wynika częstotliwość zaciągania nieczystości rytualnej spowodowanej kontaktem ze zwłokami. Przepisy dotyczące obowiązkowych oczyszczeń po kontakcie ze sferą śmierci nie tylko stanowią skuteczną barierę przed dalszym rozlewaniem się nieczystości, ale wręcz konstytuują kordon ochronny, granicę, która wyłącza zmarłych wraz z kręgiem opłakujących ich krewnych i żałobników „z tego świata”. Po wejściu na czas pogrzebu i żałoby (zwykle trwała ona siedem dni - Rdz 50,10; 1 Sm 31,13; Syr 22,12; por. jednak 2 Sm 1,12; 3,35: jeden dzień; Lb 20,29; Pwt 21,13; 34,8: trzydzieści dni) w świat zmarłych rytualne oczyszczenie umożliwiało zaraz potem powrót żywych do „tego świata”"146.

Lb 19 stanowi kolejny etap w podejściu do tych zagadnień. Tylko teoretycznie, czy także praktycznie (w obrębie samej Jerozolimy?) - nie mamy w tej kwestii żadnej pewności - wyraża potrzebę zaangażowania się wszystkich w troskę o zachowanie czystości rytualnej mimo nieuniknionego w życiu codziennym kontaktu ze zmarłymi lub tym, co z nimi pozostaje związane. Kolejne odsłony tego problemu w tradycji rabinicznej (m.Parah; t.Parah), a potem także chrześcijańskiej (Hbr 9,11-14: nie kult ofiarniczy, lecz osoba Jezusa Chrystusa) pokazują nie tylko, że podejście do tych kwestii ewoluowało, ale ewoluował także stosunek do samej procedury opisanej w Lb 19.

Wspomniany już unikatowy charakter rytuału z Lb 19 wyraża się najpierw $\mathrm{w}$ wyjątkowym sposobie dokonywania oczyszczenia ( $\mathrm{w}$ trzecim i siódmym dniu; tak jeszcze tylko podczas oczyszczenia po bitwie w Lb 31,19-23). Potem w tym, że wszystko odbywa się poza obozem, ale udział w jego procedowaniu mają zarówno

$146 \mathrm{Z}$ tego powodu m.in. zakazane były z czasem zbyt radykalne formy okazywania żałoby (nacięcia skóry, przesadne obcinanie włosów), które - jako oznaki solidarności ze zmarłymi - trwałyby dłużej niż dopuszczalny czas żałoby. Por. J. Lemański, Czy w Biblii istnieje zakaz czynienia tatuaży?, „Studia Paradyskie” 28 (2018), s. 29-44. 
kapłani, jak i świeccy. Wyjątkowe jest wreszcie także to, że kapłani zaciągają nieczystość w wyniku uczestniczenia w rytuale przygotowania wody oczyszczenia. To, że przygotowanie takiej wody wymagało zabicia i spalenia odpowiedniej krowy, zebrania popiołu i wykonania z jego pomocą, poprzez zmieszanie z wodą żywą, odpowiedniej mikstury mającej moc oczyszczającą, nie tłumaczy wystarczająco przyczyn zaciągnięcia rytualnej nieczystości. Zabijanie i tym samym kontakt ze śmiercią było czymś normalnym w systemie ofiarniczym. Nie powodowało to jednak zaciągnięcia nieczystości. Tym razem wszystko odbywa się poza systemem ofiarniczym, niejako na jego obrzeżach, imitując ofiary oczyszczające za grzech i wywołując podobne do nich skutki, ale takimi ofiarami jednocześnie nie będąc. Wydaje się zatem, że prawodawca chce z jednej strony zachować rytualny charakter obrzędów i pozostawić je pod nadzorem kapłanów. Z drugiej zaś ma na celu zachowanie jak najszerszego dostępu do rytualnego oczyszczenia $\mathrm{z}$ pomocą wody zmieszanej z popiołem z czerwonej krowy, będąc jednocześnie świadomy, że cała procedura ma i powinna zachować charakter pozakultowy.

\section{Bibliografia}

Ashley T.R., The Book of Numbers (NICOT), Grand Rapids 1993.

Baumgart A.I., The Paradox of the Red Heifer, „Vetus Testamentum” 43 (1993), s. 442-451.

Baumgarten J., The Red Cow Purification Rites in Qumran Texts, „Journal of Jewish Studies” 46 (1995), s. 112-119.

Block D.I., The Book of Ezechiel. Chapters 25-48 (NICOT), Grand Rapids-Cambridge 1998.

Boda M.J., The Book of Zechariah (NICOT), Grand Rapids-Cambridge.

Bowman J., Did the Qumran Sect Burn the Red Heifer?, „Revue de Qumran” 1 (1958), s. 73-84.

Brenner A., Colour Terms in the Old Testament (JSOT.S 21), Sheffield 1982.

The Brown-Driver-Briggs Hebrew and English Lexicon, red. F. Brown i in., Boston $1999^{4}$ [= $\mathrm{BDB}]$.

Budd Ph.P, Numbers (WBC 5), Waco 1984.

Clines D.J.A, The Dictionary of Classical Hebrew, t. 1-8, Sheffield 1993-2011 [= DCH].

Cole R.D., Numbers (NAC 3B), Nashville 2000.

Crüsemann F., The Torach. Theology and Social History of Old Testament Law, Edinburgh 1996.

Davies E.D., Numbers (NCBC), Grand Rapids 1995.

Dillmann A., Die Bücher Numeri, Deuteronomium und Josua (KeH AT 13), Leipzig $1886^{2}$.

Fischer G., Jeremia 1-25 (HThKAT), Freiburg-Basel-Wien 2005. 
Frymer-Kensky T., Pollution and Purification in Biblical Israel, w: The Word of the Lord Shall Go Forth, red. C.L. Meyers, M. O'Connor, Winona Lake 1983, s. 399-414.

Gesenius Hebräische und aramäisches Handwörterbuch über das Alte Testament, t. 1-7, red. R. Meyer, H. Donner, Berlin 1987-201218 [= Ges18].

Gilders W.K., Blood Ritual in the Hebrew Bible. Meaning and Power, Baltimore-London 2004.

Goldingay J., Old Testament Thelogy, t. 2: Israel's Faith, Downers Grove 2006.

Gorman F.H., The Ideology of Ritual: Space, Time, and Status in the Priestly Thelogy (JSOT.S 91), Sheffield 1990.

Gray G., A Critical and Exegetical Commentary on Numbers (ICC), Edinburgh 1903.

Harrington H.K., Red Heifert, w: The New Interpreter's Dictionary of the Bible, red. K.D. Sakenfeld, Nashville 2009, s. 749-750.

Harrison R.K., The Biblical Problem of Hyssop, „Evangelical Quarterly” 26 (1954), s. 218-224.

Hertz J.H., The Pentateuch and Haftorahs, London $1978^{2}$.

Holzinger H., Numeri (KHC 4), Tübingen 1903.

Kiuchi N., The Puryfication Offering in the Priestly Literature: Its Meaning and Function (JSOT.S 56), Sheffield 1987.

Knierim R.P., Coats G.W., Numbers (FOTL 4), Grand Rapids-Cambridge 2005.

Knohl I., The Sanctuary of Silence. The Priestly Torah and the Holiness School, tłum. H.J. Feldman, P. Rodman, Minneapolis 1995.

Lemański J., Hebrajski szeol na tle wyobrażeń eschatologicznych sąsiednich kultur, „Scripta Biblica et Orientalia" 3 (2011), s. 67-97.

Lemański J., Od Ducha Bożego/Jhwh do Ducha Świętego, w: Scripturae Lumen. Biblia i jej oddziaływanie, t. 8: Duch Święty, Tarnów 2016, s. 63-84.

Lemański J., Czy w Biblii istnieje zakaz czynienia tatuaży?, „Studia Paradyskie” 28 (2018), s. $29-44$.

Lemański J., O właściwe rozumienie greckiego pojęcia „dusza” (psychē) stosowanego w Starym Testamencie, w: Problem psychofizyczny, czyli pytanie o istnienie i nature duszy, red. J. Lemański, P. Goniszewski, Szczecin 2019, s. 11-64.

Lemański J., Biblijne ordalia? Od procedury „sądu Bożego” do ceremoniału kultowego (Lb 5,11-31), „Studia Koszalińsko-Kołobrzeskie” 27 (2020), s. 87-122.

Leveen A., „Lo we perish”. A Reading of Numbers 17,27-20,29, w: Torah and the Book of Numbers, red. C. Frevel, T. Pola, A. Schart, Tübingen 2013, s. 248-272.

Levine B.A., Numbers 1-20 (AB 4a), New York 1993.

Lurker M., Słownik obrazów i symboli biblijnych, tłum. K. Romaniuk, Poznań 1989.

Łach S., Księga Liczb (PŚST II-2), Poznań-Warszawa 1970. 
Michel D., Nepeš als Leichnam?, „Zeitschrift für Althebräistik” 7 (1994), s. 81-84.

Milgrom J., The Paradoks of the Red Cow (Num 19), „Vetus Tesamentum” 31 (1981), s. 62-72.

Milgrom J., Numbers. The JPS Torah Commentary, Philadelphia-New York 1989.

Milgrom J., Wright D.P., niddâ, w: Theological Dictionary of the Old Testament, t. 9, Grand Rapids-Cambridge 1998 [= TDOT], s. 232-234.

Nihan C., The Holiness Code between D and P. Some Comments on the Function and Significance of Leviticus 17-26 in the Composition of the Torah, w: Das Deuteronomium zwischen Pentateuch und Deuteronomistischem Geschichtswerk (FRLANT 206), red. E. Otto, R. Achenbach, Göttingen 2004, s. 81-122.

Noth M., Das vierte Buch Mose. Numeri (ATD 7), Göttingen 1966.

Olyan S.M., Biblical Mourning. Ritual and Social Dimensions, Oxford 2004.

Oorschot J. van, Lost in Translation, Regain by Exegesis. Npš alttestamentlischer Verwendung und Funktion, w: Anthropologie(n) des Alten Testaments, red. J. van Oorchot, A. Wagner, Leipzig 2015, s. 117-131.

Otto E., Deuteronomium 12,1-23,15 (HThKAT), Freiburg-Basel-Wien 2016.

Rad G. von, Teologia Starego Testamentu, tłum. B. Widła, Warszawa 1986.

Rendtorff R., Die Gesetze in der Priesterschrift (FRLANT 44), Göttingen 1954.

Scharbert J., Numeri (NEB 27), Würzburg 1992.

Scheftelowitz I., Das Opfer der roten Kuh (Num 19), „Zeitschrift für die alttestamentlische Wissenschaft" 39 (1921), s. 113-123.

Schmidt L., Das 4. Buch Mose. Numeri 10,11-36,13 (ATD 7,2), Göttingen 2004.

Schmitt R., Magie im Alten Testament (AOAT 313), Münster 2004.

Seebass H., Numeri. Kapitel 10,11-22,1 (BK IV/2), Neukirchen-Vluyn 2003.

Słownik mitologii Mezopotamii, red. J. Black, A. Green, Katowice 1998.

Snaith N.H., Leviticus and Numbers (NCB), London 1967.

Sprinkle J.M., Red Heifer, w: Dictionary of the Old Testament. Pentateuch, red. T.D. Alexander, D.W. Baker, Downers Grove-Leicester 2003, s. 669-670.

Staubli Th., Die Bücher Levitikus und Numeri (NSK.AT 3), Stuttgart 1996.

Szczepanowicz B., Atlas roślin biblijnych. Pochodzenie, miejsca w Biblii i symbolika, Kraków 2004.

Vaulx J. de, Les Nombres (SB), Paris 1972.

Vaux R. de, Instytucje Starego Testamentu, t. I-II, Poznań 2004.

Wefing S., Beobachtungen zum Ritual mit der roten Kuh (Num 19,1-10a), „Zeitschrift für die alttestamentlische Wissenschaft" 93 (1981), s. 341-364.

Wellhausen J., Die Composition des Hexateuchs und der historischen Bücher des Alten Testaments, Berlin $1899^{3}$. 
Westermann C., nepeš, Seele, w: Theologisches Handwörterbuch zum Alten Testament, t. 2, red. C. Westermann, E. Jenni, Gütersloh 1975; $1994^{4}$ [= THAT], s. 71-96.

Wielki słownik hebrajski-polski i aramejsko-polski Starego Testamentu, t. 1-2, red. L. Koehler, W. Baumgartner, J.J. Stamm, Warszawa 2008 [= KBL].

Wolff H.W., Anthropologie des Alten Testaments, Gütersloh 2010.

Wolters A., Zechariah (HCOT), Leuven-Paris-Walpole 2014.

Wright D.P., Heifer, Red, w: The Anchor Bible Dictionary, t. 3, red. D.N. Freedman, New York 1992 [= ABD], s. 115-116.

\section{„WODA OCZYSZCZENIA” I JEJ PARAKULTOWE ZASTOSOWANIE (LB 19,1-22) JAKO PROBLEM EGZEGETYCZNY I TEOLOGICZNY}

\section{Streszczenie}

Rytuał uboju czerwonej krowy, przygotowania wody oczyszczenia i jej zastosowania w przypadkach kontaminacji poprzez kontakt ze sferą śmierci wydaje się nietypowy i umieszczony nie na swoim miejscu w obecnej, kanonicznej wersji Księgi Liczb. W tym artykule podjęta jest próba uzasadnienia, dlaczego należy uznać, że Lb 19 znajduje się mimo wszystko we „właściwym” miejscu. Perykopa klasyfikowana jest tu jako tekst postkapłański, w którym wprowadza się nowy aspekt: dbałość o czystość rytualną sanktuarium i społeczność mimo „codziennych” kontaktów ze sferą śmierci oraz objęcie jej kontrolą ze strony kapłanów. Nowy aspekt to właśnie ta troska o zachowanie czystości rytualnej wspólnoty mimo nieuniknionego kontaktu $\mathrm{z}$ ciałami zmarłymi. Rytuał w niej opisany mobilizuje wszystkie siły, jakie drzemią we wspólnocie, do obrony przed taką nieuniknioną kontaminacją i oddaleniem od Boga, źródła życia.

Unikatowy charakter rytuału z Lb 19 wyraża się najpierw w wyjątkowym sposobie dokonywania oczyszczenia ( $\mathrm{w}$ trzecim i siódmym dniu), a potem także w tym, że wszystko odbywa się poza obozem, ale swój udział w jego procedowaniu mają zarówno kapłani, jak i świeccy. Wyjątkowe jest wreszcie także to, że kapłani zaciągają nieczystość w wyniku uczestniczenia w rytuale przygotowania wody oczyszczenia. Wszystko odbywa się tu poza system ofiarniczym, niejako na jego obrzeżach, imitując ofiary oczyszczające za grzech i wywołując podobne do nich skutki, ale takimi ofiarami jednocześnie nie będąc. W ten sposób prawodawca chce z jednej strony zachować rytualny charakter obrzędów i pozostawić je pod nadzorem kapłanów. Z drugiej zaś ma na celu zachowanie jak najszerszego dostępu do rytualnego oczyszczenia z pomocą wody zmieszanej z popiołem z czerwonej krowy. Jednocześnie jest świadomy, że cała procedura ma i powinna zachować charakter pozakultowy.

Słowa kluczowe: czerwona krowa, oczyszczenie, woda oczyszczenia, śmierć 


\section{Nota autorska}

Janusz Lemański - duchowny rzymskokatolicki, prof. nauk teologicznych, biblista, kierownik Katedry Teologii Biblijnej i Historii Kościoła w Instytucie Nauk Teologicznych Uniwersytetu Szczecińskiego; e-mail: janusz.lemanski@usz.edu.pl. 